\title{
New Cardenolides from Biotransformation of Gitoxigenin by the Endophytic Fungus Alternaria eureka 1E1BL1: Characterization and Cytotoxic Activities
}

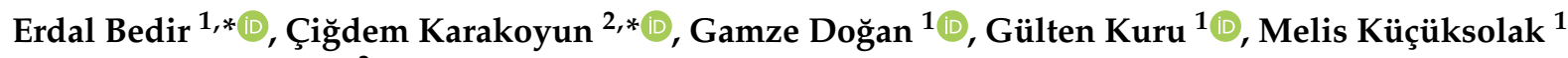 \\ and Hasan Yusufoğlu ${ }^{3}$ \\ 1 Department of Bioengineering, Faculty of Engineering, İzmir Institute of Technology, \\ 35430 Urla-İzmir, Turkey; gamzedogan@iyte.edu.tr (G.D.); gultenkuru@iyte.edu.tr (G.K.); \\ meliskucuksolak@iyte.edu.tr (M.K.) \\ 2 Department of Pharmacognosy, Faculty of Pharmacy, Ege University, 35100 Bornova-İzmir, Turkey \\ 3 Department of Pharmacognosy, College of Pharmacy, Prince Sattam Bin Abdulaziz University, \\ Al-Kharj 11942, Saudi Arabia; h.yusufoglu@psau.edu.sa \\ * Correspondence: erdalbedir@iyte.edu.tr (E.B.); cigdem.karakoyun@ege.edu.tr (Ç.K.); \\ Tel.: +90-232-750-7389 (E.B.); +90-232-311-2598 (Ç.K.)
}

check for updates

Citation: Bedir, E.; Karakoyun, Ç.; Doğan, G.; Kuru, G.; Küçüksolak, M.; Yusufoğlu, H. New Cardenolides from Biotransformation of Gitoxigenin by the Endophytic Fungus Alternaria eureka 1E1BL1: Characterization and Cytotoxic Activities. Molecules 2021, 26, 3030. https://doi.org/10.3390/ molecules 26103030

Academic Editors: Horváth Györgyi, İhsan Çalış and Agnieszka Ludwiczuk

Received: 12 March 2021

Accepted: 12 May 2021

Published: 19 May 2021

Publisher's Note: MDPI stays neutral with regard to jurisdictional claims in published maps and institutional affiliations.

Copyright: (C) 2021 by the authors Licensee MDPI, Basel, Switzerland. This article is an open access article distributed under the terms and conditions of the Creative Commons Attribution (CC BY) license (https:// creativecommons.org/licenses/by/ $4.0 /)$.

\begin{abstract}
Microbial biotransformation is an important tool in drug discovery and for metabolism studies. To expand our bioactive natural product library via modification and to identify possible mammalian metabolites, a cytotoxic cardenolide (gitoxigenin) was biotransformed using the endophytic fungus Alternaria eureka 1E1BL1. Initially, oleandrin was isolated from the dried leaves of Nerium oleander L. and subjected to an acid-catalysed hydrolysis to obtain the substrate gitoxigenin (yield; 25\%). After 21 days of incubation, five new cardenolides 1, 3, 4, 6, and 8 and three previouslyidentified compounds 2, 5 and 7 were isolated using chromatographic methods. Structural elucidations were accomplished through 1D/2D NMR, HR-ESI-MS and FT-IR analysis. A. eureka catalyzed oxygenation, oxidation, epimerization and dimethyl acetal formation reactions on the substrate. Cytotoxicity of the metabolites were evaluated using MTT cell viability method, whereas doxorubicin and oleandrin were used as positive controls. Biotransformation products displayed less cytotoxicity than the substrate. The new metabolite 8 exhibited the highest activity with $\mathrm{IC}_{50}$ values of $8.25,1.95$ and $3.4 \mu \mathrm{M}$ against A549, PANC-1 and MIA PaCa-2 cells, respectively, without causing toxicity on healthy cell lines (MRC-5 and HEK-293) up to concentration of $10 \mu \mathrm{M}$. Our results suggest that $A$. eureka is an effective biocatalyst for modifying cardenolide-type secondary metabolites.
\end{abstract}

Keywords: Nerium oleander L.; cardenolides; oleandrin; gitoxigenin; biotransformation; endophytic fungus; Alternaria eureka 1E1BL1; cytotoxicity

\section{Introduction}

Microbial biotransformation is one of the most preferred and powerful procedures in natural product drug discovery and development studies enabling specific biochemical modifications of substrate molecules [1]. An enzyme, a living cell, or an inactivated microorganism containing several specific enzymes can be used for biotransformation processes leading to the production of new drug candidates with better properties. Microbial enzyme systems are able to catalyze regio- and stereo-specific reactions which are challenging issues in chemical synthesis [2-4]. These enzymes are to employ diverse chemical reactions such as oxygenation, oxidation/reduction, cyclization, epoxidation, dehydrogenation, acetylation/deacetylation and epimerization. Besides, most favored metabolic products of the given substrate can be predicted especially via fungal biotransformation [5]. Thus, foreseeing metabolic fate of drug candidates provides insight into mammalian drug metabolism at preclinical stages. Microbial transformation, as a modern, 
time- and cost-efficient molecular modification approach, is of increasing interest to pharmaceutical industries. Also, the use of microbial biotransformation has become one of the essential parts of white biotechnology and green chemistry movements due to requiring less energy and creating less waste [6].

Nerium oleander L. is a perennial evergreen shrub that belongs to the family Apocynaceae. It is a widely cultivated ornamental herb, native to the Mediterranean region. In ethnobotanical literature, $N$. oleander is reported as a traditional medicine being used as abortifacient and for the treatment of a wide range of diseases such as dermatitis, eczema, skin cancer, viral infections, asthma, epilepsy, malaria, tumors, corns, leprosy, ringworm, and warts [7]. All parts of this plant are known to be poisonous to human beings, animals, and some insects. Both toxic effects and bioactivities of $N$. oleander are mainly attributed to the cardiac glycoside content of the plant $[8,9]$.

Recently, N. oleander has attracted a great deal of attention due to promising anticancer activity of two patented water extracts: Anvirzel ${ }^{\circledR}$ and Breastin ${ }^{\circledR}[10,11]$. Anvirzel ${ }^{\circledR}$, a sterile hot aqueous extract of $N$. oleander, has been recognized as a potent anticancer agent against advanced solid tumors. A phase I clinical trial study demonstrated the safety of intramuscular administration of Anvirze ${ }^{\circledR}$ up to the dose of $1.2 \mathrm{~mL} / \mathrm{m}^{2} /$ day. Other clinically tested anticancer natural product, Breastin ${ }^{\circledR}$, is the cold-water extract of N. oleander exhibiting selective antitumor activities against brain tumor SF268, lung carcinoma LXF1221L, pancreas carcinoma PANC-1 and prostate cancer DU 145. Phytochemical studies have demonstrated that potent anticancer activity of the water extract of $N$. oleander mostly arises from its monoglycosidic cardenolide content such as oleandrin, odoroside A, odoroside $\mathrm{H}$, and neritaloside [11]. In particular, Anvirzel ${ }^{\circledR}$ and Breastin ${ }^{\circledR}$ contain considerably high amounts of oleandrin, which is regarded as the principal active constituent anticancer [12].

Oleandrin, possesses a cardenolide-type aglycone called oleandrigenin together with a dideoxy sugar moiety called oleandrose (Figure 1). The main physiological action of cardenolides is cardiotonic effect and depends on disrupting sodium potassium pump $\left(\mathrm{Na}^{+} / \mathrm{K}^{+}\right.$-ATPase) functions leading to increased levels of intracellular calcium ions $\left(\mathrm{Ca}^{++}\right)$. Thus, cardenolide-type compounds generate positive inotropic and negative chronotropic action on heart muscles, and consistently improve the prognosis of patients with congestive heart failure. In addition to anticancer and heart contractility promoting effects, oleandrin is also known to possess anti-oxidant, diuretic, anti-inflammatory, neuroprotective and anti-viral activities [13-15]. Furthermore, a recent study has reported that oleandrin is a potent anti-viral agent providing both prophylactic and curative treatment for COVID-19. According to in vitro experiments, administration of oleandrin at 0.05 and $0.1 \mu \mathrm{g} / \mathrm{mL}$ doses resulted in 78- and 100-fold reduction in infectious virus production, respectively [16].

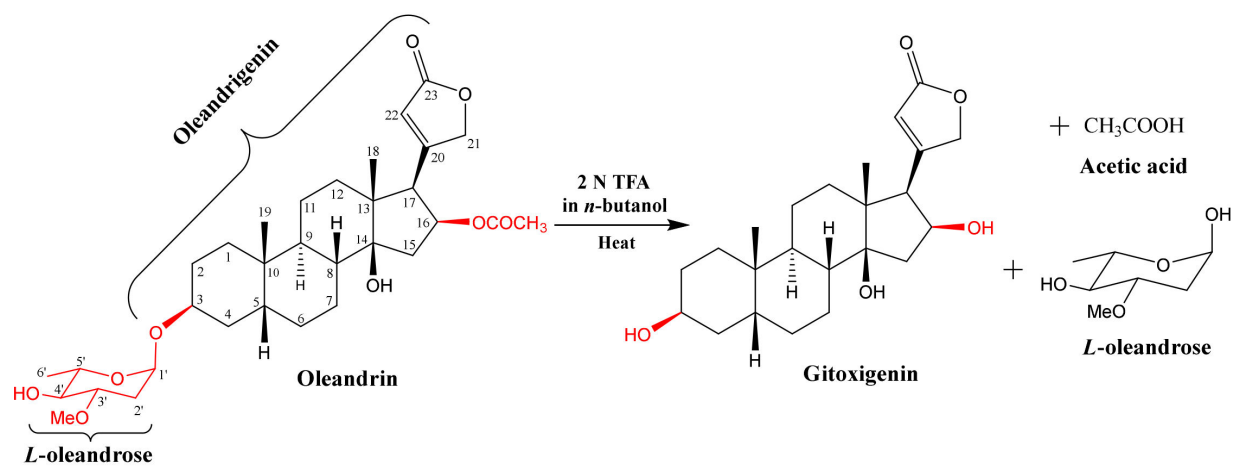

Figure 1. Acid-catalysed hydrolysis of cardiac glycoside oleandrin and structures of oleandrin, gitoxigenin and L-oleandrose (TFA: trifluoroacetic acid).

Gitoxigenin is desacetyl congener of oleandrigenin (Figure 1), of which the concentration in biological samples of patients is commonly monitored as one of the follow-up markers in cases of oleander poisoning [17]. Despite the fact that high concentrations of 
gitoxigenin have poisonous effects, it has been known that certain doses have therapeutic effects on congestive heart failure and atrial arrhythmia. Thus, gitoxigenin is a promising natural product present in a variety of plants $[18,19]$.

Based on our latest literature search, there are only a few studies on biological activity of gitoxigenin [20-24]. Low et al. screened 502 natural products for anti-viral activity against dengue virus via immunofluorescence assay with the hit criteria of $\geq 40 \%$ inhibition, and gitoxigenin was detected as one of the 30 hit compounds exhibiting $49.01 \%$ inhibition [25]. Xie et al. conducted a high throughput screening study on more than 3000 compounds and reported potent anticancer activity of gitoxigenin against human colon cancer cell line [26]. Milutinovic et al. demonstrated the anticancer effect of gitoxigenin against HeLa cells through a homogeneous plate-reader assay $\left(\mathrm{EC}_{50}: 2.1 \mu \mathrm{M}\right)$ [17]. Also, cytotoxic activity of gitoxigenin against three cancerous cell lines (human renal adenocarcinoma, TK-10; human breast adenocarcinoma, MCF-7; and human melanoma, UACC-62) was investigated via sulphorhodamine B colorimetric method in a previous work by López-Lázaro et al., and gitoxigenin was reported as potent cytotoxic agent showing $\mathrm{IC}_{50}$ values in the range of 0.415 to $2.83 \mu \mathrm{M}$ [21].

Despite the promising potential of cardiac glycosides as drug candidates, their use in medicinal applications is limited because of their aggressive pharmacokinetic and toxicologic behaviours. Thus, there is an urgent need for research on drug development studies on cardenolide glycosides and their aglycones, in order to overcome these challenges. For this purpose, biotransformation might be a useful tool for investigation of structure-activity relationships (SAR), prediction of drug metabolism and discovery of new drug candidates with increased bioavailability. However, only a few studies have been conducted on microbial biotransformation of gitoxigenin $[27,28]$.

Recently our group have performed molecular modification studies on bioactive natural products and reported interesting findings [29-32]. Taking into consideration of these findings and our preliminary screening studies, A. eureka 1E1BL1 was proven to have high transformation capacity on steroidal nuclei. Therefore, within the first part of our current work on the constituents of Nerium oleander L., the cardiac glycoside oleandrin was transformed using the same endophytic fungus in addition to Phaeosphaeria sp. 1E4CS-1, which resulted in isolation of five new oleandrin derivatives with significant cytotoxic activities [33].

In the present study, we aimed to perform a microbial biotransformation study on gitoxigenin, which was obtained by acid-catalyzed hydrolysis of oleandrin. Incubation of gitoxigenin with A. eureka 1E1BL1 has led to the production of five previously undescribed cardenolides together with three known metabolites. Microbial oxygenations at C-7 and C-12 sites were observed while dimethyl acetal formation on gitoxigenin core structure was reported here for the first time. All isolates and the substrate were evaluated for cytotoxic activity against several cancer cell lines (PANC-1, MIA PaCa-2, DU 145 and A549) and two healthy cell lines (MRC-5 and HEK-293) serving doxorubicin and oleandrin as positive controls.

\section{Results and Discussion}

2.1. Isolation and Purification of Oleandrin from N. oleander L. and Preparation of Substrate Gitoxigenin and Obtaining Biotransformation Products

Oleandrin $(4.0 \mathrm{~g})$ was isolated from the dried leaves of N. oleander $\mathrm{L}$. and subjected to an acid-catalyzed hydrolysis affording gitoxigenin ( $25 \%$ yield) (Figure 1$)$. The structural identification of gitoxigenin was established unambiguously by spectral methods (see Section 3.6 and Table S1, in the Supplementary Materials). A twenty-one-day biotransformation experiment of gitoxigenin by Alternaria eureka 1E1BL1 yielded eight metabolites (Figure 2). 


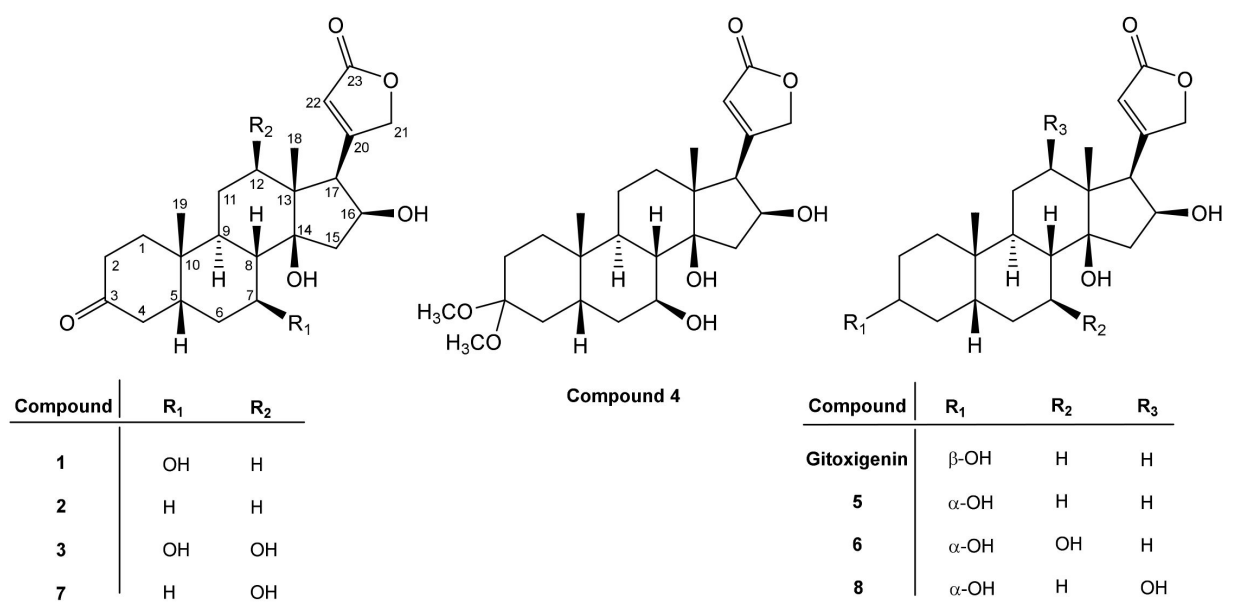

Figure 2. Chemical structures of gitoxigenin (substrate) and eight biotransformation products transformed by A. eureka 1E1BL1.

\subsection{Structural Elucidations of Biotransformation Products}

The ${ }^{1} \mathrm{H}$ and ${ }^{13} \mathrm{C}$ NMR data of the new metabolites $1,3,4,6$ and 8 are presented in Tables 1 and 2, respectively. Furthermore, the NMR data of 2 and 7, which were tentatively identified in the previous studies, are herein reported for the first time (Tables 1 and 2).

The molecular formula of $\mathbf{1}$ was determined as $\mathrm{C}_{23} \mathrm{H}_{32} \mathrm{O}_{6}$ based on the major ion peak at $m / z 403.2123[\mathrm{M}-\mathrm{H}]^{-}$(calcd. 403.2126 for $\mathrm{C}_{23} \mathrm{H}_{32} \mathrm{O}_{6}[\mathrm{M}-\mathrm{H}]^{-}$). The characteristic hydroxymethine proton at $\mathrm{C}-3$ was not present in the ${ }^{1} \mathrm{H}-\mathrm{NMR}$ spectrum. Besides, the downfield shifts of C-2 and C-4 (ca. $8.3 \mathrm{ppm}$ and $8.7 \mathrm{ppm}$ ) compared to those of gitoxigenin implied an alteration on the ring A. Accordingly, in the ${ }^{13} \mathrm{C}-\mathrm{NMR}$ spectrum, the carbonyl signal observed at $\delta_{C} 212.7$ was readily assigned to $C-3$, which was substantiated by the observation of $\mathrm{HMBC}$ cross-peaks from C-3 $\left(\delta_{\mathrm{C}} 212.7\right)$ to one of $\mathrm{H}_{2}-2\left(\delta_{\mathrm{H}} 2.21, \mathrm{td}, J=14.4\right.$; $5.3 \mathrm{~Hz})$ and $\mathrm{H}_{2}-4\left(\delta_{\mathrm{H}} 2.43, \mathrm{~m}\right)$ protons. Apart from the characteristic low-field signals observed, an additional oxymethine signal at $\delta_{\mathrm{H}} 3.84$ was apparent, corresponding to a carbon signal at $\delta_{C} 69.1$ in the HSQC spectrum. When the COSY spectrum was inspected starting from the $\mathrm{H}_{2}-4$ resonances $\left(\delta_{\mathrm{H}} 2.10\right.$ and 2.43), the spin system to the new resonance at $\delta_{\mathrm{H}} 3.84$ was tracked clearly $\left[\mathrm{H}_{2}-4 / \mathrm{H}-5\left(\delta_{\mathrm{H}} 1.86, \mathrm{~m}\right) / \mathrm{H}_{2}-6\left(\delta_{\mathrm{H}} 1.50\right.\right.$ and $\left.1.83 \mathrm{~m}\right) / \mathrm{H}-7\left(\delta_{\mathrm{H}}\right.$ $3.84, \mathrm{td}, J=10.6,4.9 \mathrm{~Hz})]$, suggested $\mathrm{H}-7$ to be an oxymethine proton. The significant downfield shifts of $C-6\left(\delta_{C} 35.9\right)$ and $C-8\left(\delta_{C} 45.6\right)$ (ca. 8.2 and 2.8 ppm compared to those of gitoxigenin, respectively), and the long-distance correlations in the HMBC spectrum from C-7 $(\delta 69.1)$ to $\mathrm{H}_{2}-6\left(\delta_{\mathrm{H}} 1.50 \mathrm{~m} ; 1.83 \mathrm{~m}\right)$ and $\mathrm{H}-8\left(\delta_{\mathrm{H}} 1.69, \mathrm{dd}, J=11.8 ; 10.4 \mathrm{~Hz}\right)$ verified the monooxygenation at $\mathrm{C}-7$ position (Figure 3 ).

The relative orientation of the hydroxy group was determined using 2D-NOESY. The H-7 $\left(\delta_{\mathrm{H}} 3.84\right)$ signal showed NOESY correlation with the $\alpha$-oriented H-9 $\left(\delta_{\mathrm{H}} 1.58 \mathrm{~m}\right)$ establishing the $\beta$-orientation of the hydroxy group at C-7. Consequently, the structure of compound 1 was characterized as $7 \beta$-hydroxy-3-oxogitoxigenin. 
Table 1. ${ }^{1} \mathrm{H}$ NMR data of gitoxigenin and compounds $1-8\left(\delta_{\mathrm{H}}(\mathrm{ppm}),(J, \mathrm{~Hz})\right)$.

\begin{tabular}{|c|c|c|c|c|c|c|c|c|c|}
\hline Position & Gitoxigenin & 1 & 2 & 3 & 4 & 5 & 6 & 7 & 8 \\
\hline 1 & $1.22 \mathrm{~m} ; 1.27 \mathrm{~m}$ & $1.41 \mathrm{~m} ; 1.93 \mathrm{~m}$ & $1.45 \mathrm{~m} ; 2.00 \mathrm{~m}$ & $\begin{array}{c}1.48 \mathrm{~m} ; 2.05 \mathrm{dd} \\
(14.2,4.5)\end{array}$ & $1.25 \mathrm{~m} ; 1.65 \mathrm{~m}$ & $\begin{array}{l}1.04 \mathrm{td}(14.2,3.5) \\
1.82 \mathrm{~m}\end{array}$ & $\begin{array}{l}1.06 \mathrm{~d}(14.5) \\
1.80 \mathrm{~m}\end{array}$ & $1.45 \mathrm{~m} ; 2.11 \mathrm{~m}$ & $\begin{array}{c}1.11 \mathrm{td}(14.2,3.4) ; \\
1.85 \mathrm{~m}\end{array}$ \\
\hline 2 & $1.24 \mathrm{~m} ; 1.36 \mathrm{~m}$ & $\begin{array}{c}2.12 \mathrm{~m} ; 2.21 \mathrm{td} \\
\quad(14.4,5.3)\end{array}$ & $\begin{array}{c}2.20 \mathrm{~d}(16.1) \\
2.32 \mathrm{dd}(14.5,6.4)\end{array}$ & $\begin{array}{c}2.12 \mathrm{~m} ; 2.47 \mathrm{td} \\
(14.5,5.1)\end{array}$ & $1.26 \mathrm{~m} ; 1.77 \mathrm{~m}$ & $1.37 \mathrm{~m} ; 1.65 \mathrm{~m}$ & $\begin{array}{l}1.65 \mathrm{q}(12.5) \\
1.96 \mathrm{~m}\end{array}$ & $\begin{array}{c}2.12 \mathrm{~m} ; 2.57 \mathrm{dd} \\
\quad(14.4,5.5)\end{array}$ & $1.39 \mathrm{~m} ; 1.69 \mathrm{~m}$ \\
\hline 3 & $3.82 \mathrm{t}(2.8)$ & - & - & - & - & $3.56 \mathrm{~m}$ & $3.85 \mathrm{~m}$ & - & $3.59 \mathrm{~m}$ \\
\hline 4 & $\begin{array}{c}1.09 \mathrm{~m} ; 1.67 \mathrm{td} \\
(13.7,3.2)\end{array}$ & $2.10 \mathrm{~m} ; 2.43 \mathrm{~m}$ & $2.06 \mathrm{~m} ; 2.62 \mathrm{~m}$ & $2.12 \mathrm{~m} ; 2.66 \mathrm{t}(14.3)$ & $1.55 \mathrm{~m} ; 1.77 \mathrm{~m}$ & $1.49 \mathrm{~m} ; 1.74 \mathrm{~m}$ & $1.92 \mathrm{~m} ; 1.99 \mathrm{~m}$ & $1.97 \mathrm{~m} ; 2.81 \mathrm{t}(14.3)$ & $1.53 \mathrm{~m} ; 1.70 \mathrm{~m}$ \\
\hline 5 & $1.54 \mathrm{~m}$ & $1.86 \mathrm{~m}$ & $1.84 \mathrm{~m}$ & $1.88 \mathrm{~m}$ & $1.67 \mathrm{~m}$ & $1.40 \mathrm{~m}$ & $1.51 \mathrm{~m}$ & $1.82 \mathrm{~m}$ & $1.45 \mathrm{~m}$ \\
\hline 6 & $0.96 \mathrm{~m} ; 1.63 \mathrm{~m}$ & $1.50 \mathrm{~m} ; 1.83 \mathrm{~m}$ & $1.37 \mathrm{~m} ; 1.90 \mathrm{~m}$ & $1.58 \mathrm{~m} ; 1.90 \mathrm{~m}$ & $1.57 \mathrm{~m} ; 1.92 \mathrm{~m}$ & $1.35 \mathrm{~m} ; 1.88 \mathrm{~m}$ & $\begin{array}{c}1.80 \mathrm{~m} ; 2.14 \mathrm{td} \\
(12.2,4.9)\end{array}$ & $1.37 \mathrm{~m} ; 1.91 \mathrm{~m}$ & $1.38 \mathrm{~m} ; 1.91 \mathrm{~m}$ \\
\hline 7 & $0.97 \mathrm{~m} ; 1.57 \mathrm{~m}$ & $3.84 \operatorname{td}(10.6,4.9)$ & $1.24 \mathrm{~m} ; 1.91 \mathrm{~m}$ & $\begin{array}{c}3.91 \mathrm{td}(11.6,11.2 \\
4.7)\end{array}$ & $3.96 \mathrm{~m}$ & $1.29 \mathrm{~m} ; 1.84 \mathrm{~m}^{*}$ & $4.26 \mathrm{~m}$ & $1.31 \mathrm{~m} ; 1.91 \mathrm{~m}$ & $1.31 \mathrm{~m} ; 1.84 \mathrm{~m}$ \\
\hline 8 & $1.34 \mathrm{~m}$ & $1.69 \mathrm{dd}(11.8,10.4)$ & $1.62 \mathrm{~m}$ & $1.71 \mathrm{~m}$ & $1.72 \mathrm{~m}$ & $1.59 \mathrm{~m}$ & $1.95 \mathrm{~m}$ & $1.65 \mathrm{~m}$ & $1.60 \mathrm{~m}$ \\
\hline 9 & $1.37 \mathrm{~m}$ & $1.58 \mathrm{~m}$ & $1.69 \mathrm{~m}$ & $1.88 \mathrm{~m}$ & $1.54 \mathrm{~m}$ & $1.70 \mathrm{~m}$ & $1.77 \mathrm{~m}$ & $1.89 \mathrm{~m}$ & $1.72 \mathrm{~m}$ \\
\hline 10 & - & - & - & - & - & - & - & - & - \\
\hline 11 & $0.94 \mathrm{~m} ; 1.11 \mathrm{~m}$ & $1.31 \mathrm{~m} ; 1.37 \mathrm{~m}$ & $1.32 \mathrm{~m} ; 1.46 \mathrm{~m}$ & $1.45 \mathrm{~m} ; 1.63 \mathrm{~m}$ & $1.25 \mathrm{~m} ; 1.41 \mathrm{~m}$ & $1.21 \mathrm{~m} ; 1.42 \mathrm{~m}^{*}$ & $1.25 \mathrm{~m} ; 1.35 \mathrm{~m}$ & $1.30 \mathrm{~m} ; 1.66 \mathrm{~m}$ & $1.30 \mathrm{~m} ; 1.61 \mathrm{~m}$ \\
\hline 12 & $1.11 \mathrm{~m} ; 1.26 \mathrm{~m}$ & $1.25 \mathrm{~m} ; 1.61 \mathrm{~m}$ & $1.35 \mathrm{~m} ; 1.69 \mathrm{~m}$ & $3.36 \mathrm{dd}(11.8,4.1)$ & $1.25 \mathrm{~m} ; 1.65 \mathrm{~m}$ & $1.39 \mathrm{~m} ; 1.55 \mathrm{~m}$ & $1.31 \mathrm{~m} ; 1.49 \mathrm{~m}$ & $3.40 \mathrm{dd}(11.8,4.1)$ & $3.34 \mathrm{~m}$ \\
\hline 13 & - & - & - & - & - & - & - & - & - \\
\hline 14 & - & - & - & - & - & - & - & - & - \\
\hline 15 & $\begin{array}{l}1.49 \text { dd }(15.0,2.4) \\
2.35 \text { dd }(14.9,8.5)\end{array}$ & $\begin{array}{c}1.95 \mathrm{~m} ; 2.36 \mathrm{dd} \\
(14.2,6.4)\end{array}$ & $\begin{array}{c}1.90 \mathrm{~m} ; 2.42 \mathrm{dd} \\
(14.5,6.4)\end{array}$ & $\begin{array}{c}1.97 \mathrm{~m} ; 2.59 \mathrm{dd} \\
(14.5,7.5)\end{array}$ & $\begin{array}{c}2.05 \mathrm{~m} ; 2.40 \mathrm{dt} \\
\quad(14.4,4.8)\end{array}$ & $\begin{array}{c}1.72 \mathrm{~m} ; 2.63 \mathrm{dd} \\
(14.9,8.5)\end{array}$ & $\begin{array}{c}2.27 \mathrm{~d}(13.8) ; 2.67 \\
\mathrm{~m}\end{array}$ & $\begin{array}{c}1.79 \mathrm{~m} ; 2.49 \mathrm{dd} \\
(14.9,7.6)\end{array}$ & $\begin{array}{c}1.82 \mathrm{~m} ; 2.43 \mathrm{dd} \\
(14.7,7.6)\end{array}$ \\
\hline 17 & $2.88 \mathrm{~d}(7.9)$ & $2.91 \mathrm{~d}(6.9)$ & $2.96 \mathrm{~d}(7.1)$ & $3.58 \mathrm{~d}(7.6)$ & $2.91 \mathrm{dd}(7.0,3.0)$ & $3.14 \mathrm{~d}(7.9)$ & $3.29 \mathrm{~d}(8.0)$ & $3.59 \mathrm{~d}(7.6)$ & $3.59 \mathrm{~m}$ \\
\hline 18 & $0.66 \mathrm{~s}$ & $0.90 \mathrm{~s}$ & $0.98 \mathrm{~s}$ & $0.89 \mathrm{~s}$ & $0.96 \mathrm{~s}$ & $0.92 \mathrm{~s}$ & $1.11 \mathrm{~s}$ & $0.89 \mathrm{~s}$ & $0.87 \mathrm{~s}$ \\
\hline 19 & $0.66 \mathrm{~s}$ & $0.98 \mathrm{~s}$ & $1.02 \mathrm{~s}$ & $1.06 \mathrm{~s}$ & $0.97 \mathrm{~s}$ & $0.93 \mathrm{~s}$ & $0.93 \mathrm{~s}$ & $1.06 \mathrm{~s}$ & $0.97 \mathrm{~s}$ \\
\hline 20 & - & - & - & - & - & - & - & - & - \\
\hline 21 & $\begin{array}{l}4.96 \mathrm{~d}(18.4) ; \\
\quad 4.91 \mathrm{~m}\end{array}$ & $\begin{array}{l}4.87 \mathrm{~d}(18.3) \\
5.02 \mathrm{~d}(18.3)\end{array}$ & $\begin{array}{l}4.90 \mathrm{~d}(18.1) \\
5.05 \mathrm{~d}(18.1)\end{array}$ & $\begin{array}{l}5.03 \text { dd }(18.5,1.8) \\
5.14 \text { dd }(18.5,1.9)\end{array}$ & $4.89 \mathrm{~m} ; 5.06 \mathrm{~m}$ & $\begin{array}{l}5.11 \mathrm{dd}(18.4,1.8) \\
5.17 \mathrm{dd}(18.5,1.8)\end{array}$ & $5.57 \mathrm{~m} ; 5.69 \mathrm{~m}$ & $\begin{array}{l}5.04 \text { dd }(18.3,1.8) \\
5.18 \text { dd }(18.4,1.9)\end{array}$ & $\begin{array}{l}5.04 \mathrm{dd}(18.5,1.8) ; \\
5.19 \mathrm{dd}(18.5,1.9)\end{array}$ \\
\hline 22 & $5.71 \mathrm{~s}$ & $5.88 \mathrm{~s}$ & $5.97 \mathrm{~s}$ & $6.01 \mathrm{~s}$ & $5.97 \mathrm{~s}$ & $5.94 \mathrm{~s}$ & $6.25 \mathrm{~s}$ & $6.03 \mathrm{~s}$ & $6.03 \mathrm{~s}$ \\
\hline 23 & - & - & - & - & - & - & - & - & - \\
\hline 3-O-Me & - & - & - & - & $3.12 \mathrm{~s}$ & - & - & - & - \\
\hline 3-O-Me & - & - & - & - & $3.19 \mathrm{~s}$ & - & - & - & - \\
\hline Solvent & $\begin{array}{l}\mathrm{CD}_{3} \mathrm{OD} / \mathrm{a} \text { drop of } \\
\text { pyridine- } d_{5}\end{array}$ & $\begin{array}{c}\mathrm{CDCl}_{3} / \mathrm{a} \text { drop of } \\
\mathrm{CD}_{3} \mathrm{OD}\end{array}$ & $\mathrm{CDCl}_{3}$ & $\mathrm{CD}_{3} \mathrm{OD}$ & $\mathrm{CDCl}_{3}$ & $\mathrm{CD}_{3} \mathrm{OD}$ & Pyridine- $d_{5}$ & $\mathrm{CD}_{3} \mathrm{OD}$ & $\mathrm{CD}_{3} \mathrm{OD}$ \\
\hline
\end{tabular}


Table 2. ${ }^{13} \mathrm{C}-\mathrm{NMR}$ data of gitoxigenin and compounds $\mathbf{1}-\mathbf{8} \delta_{\mathrm{C}}(\mathrm{ppm})$.

\begin{tabular}{|c|c|c|c|c|c|c|c|c|c|}
\hline Position & Gitoxigenin & 1 & 2 & 3 & 4 & 5 & 6 & 7 & 8 \\
\hline 1 & $30.7 \mathrm{t}$ & $36.0 \mathrm{t}$ & $36.7 t$ & $37.6 \mathrm{t}$ & $32.4 \mathrm{t}$ & $36.2 \mathrm{t}$ & $35.7 t$ & $37.8 \mathrm{t}$ & $36.2 \mathrm{t}$ \\
\hline 2 & $28.5 \mathrm{t}$ & $36.8 \mathrm{t}$ & $37.2 \mathrm{t}$ & $38.9 \mathrm{t}$ & $27.5 \mathrm{t}$ & $31.3 \mathrm{t}$ & $31.8 \mathrm{t}$ & $37.9 \mathrm{t}$ & $31.2 \mathrm{t}$ \\
\hline 3 & $67.6 \mathrm{~d}$ & $212.7 \mathrm{~s}$ & $212.7 \mathrm{~s}$ & $214.5 \mathrm{~s}$ & $100.4 \mathrm{~s}$ & $72.3 \mathrm{~d}$ & $71.2 \mathrm{~d}$ & $215.9 \mathrm{~s}$ & $72.2 \mathrm{~d}$ \\
\hline 4 & $34.1 \mathrm{t}$ & $42.8 \mathrm{t}$ & $42.2 \mathrm{t}$ & $43.7 \mathrm{t}$ & $34.5 \mathrm{t}$ & $37.0 \mathrm{t}$ & $38.7 \mathrm{t}$ & $43.0 \mathrm{t}$ & $37.0 \mathrm{t}$ \\
\hline 5 & $37.3 \mathrm{~d}$ & $43.7 \mathrm{~d}$ & $43.6 \mathrm{~d}$ & $45.1 \mathrm{~d}$ & $40.1 \mathrm{~d}$ & $43.1 \mathrm{~d}$ & $43.1 \mathrm{~d}$ & $45.4 \mathrm{~d}$ & $43.1 \mathrm{~d}$ \\
\hline 6 & $27.7 \mathrm{t}$ & $35.9 \mathrm{t}$ & $26.6 \mathrm{t}$ & $37.2 \mathrm{t}$ & $37.1 \mathrm{t}$ & $28.2 \mathrm{t}$ & $38.5 \mathrm{t}$ & $27.7 \mathrm{t}$ & $28.2 \mathrm{t}$ \\
\hline 7 & $22.4 \mathrm{t}$ & $69.1 \mathrm{~d}$ & $21.5 \mathrm{t}$ & $70.3 \mathrm{~d}$ & $70.9 \mathrm{~d}$ & $22.6 t^{*}$ & $70.5 \mathrm{~d}$ & $22.4 \mathrm{t}$ & $23.0 \mathrm{t}$ \\
\hline 8 & $42.8 \mathrm{~d}$ & $45.6 \mathrm{~d}$ & $41.7 \mathrm{~d}$ & $46.8 \mathrm{~d}$ & $46.4 \mathrm{~d}$ & $43.0 \mathrm{~d}$ & $47.3 \mathrm{~d}$ & $42.1 \mathrm{~d}$ & $42.4 \mathrm{~d}$ \\
\hline 9 & $36.5 \mathrm{~d}$ & $35.8 \mathrm{~d}$ & $36.7 \mathrm{~d}$ & $33.8 \mathrm{~d}$ & $35.0 \mathrm{~d}$ & $37.4 \mathrm{~d}$ & $36.2 \mathrm{~d}$ & $34.4 \mathrm{~d}$ & $34.3 \mathrm{~d}$ \\
\hline 10 & $36.3 \mathrm{~s}$ & $35.0 \mathrm{~s}$ & $35.4 \mathrm{~s}$ & $36.0 \mathrm{~s}$ & $35.1 \mathrm{~s}$ & $35.9 \mathrm{~s}$ & $35.4 \mathrm{~s}$ & $36.2 \mathrm{~s}$ & $35.8 \mathrm{~s}$ \\
\hline 11 & $22.0 \mathrm{t}$ & $21.3 \mathrm{t}$ & $21.2 \mathrm{t}$ & $30.7 \mathrm{t}$ & $21.4 \mathrm{t}$ & $21.9 t^{*}$ & $21.5 \mathrm{t}$ & $30.7 \mathrm{t}$ & $30.5 \mathrm{t}$ \\
\hline 12 & $40.8 \mathrm{t}$ & $41.2 \mathrm{t}$ & $41.5 \mathrm{t}$ & $75.9 \mathrm{~d}$ & $42.0 \mathrm{t}$ & $40.9 \mathrm{t}$ & $40.2 \mathrm{t}$ & $76.3 \mathrm{~d}$ & $76.6 \mathrm{~d}$ \\
\hline 13 & $51.3 \mathrm{~s}$ & $49.5 \mathrm{~s}$ & $49.8 \mathrm{~s}$ & $57.2 \mathrm{~s}$ & $49.4 \mathrm{~s}$ & $51.3 \mathrm{~s}$ & $50.5 \mathrm{~s}$ & $57.6 \mathrm{~s}$ & $57.6 \mathrm{~s}$ \\
\hline 14 & $85.5 \mathrm{~s}$ & $86.0 \mathrm{~s}$ & $85.8 \mathrm{~s}$ & $87.0 \mathrm{~s}$ & $86.6 \mathrm{~s}$ & $85.6 \mathrm{~s}$ & $85.4 \mathrm{~s}$ & $86.3 \mathrm{~s}$ & $86.4 \mathrm{~s}$ \\
\hline 15 & $43.8 \mathrm{t}$ & $42.1 \mathrm{t}$ & $42.2 \mathrm{t}$ & $44.4 \mathrm{t}$ & $42.4 \mathrm{t}$ & $43.8 \mathrm{t}$ & $45.5 \mathrm{t}$ & $43.4 \mathrm{t}$ & $43.5 \mathrm{t}$ \\
\hline 16 & $73.0 \mathrm{~d}$ & $73.0 \mathrm{~d}$ & $73.2 \mathrm{~d}$ & $73.6 \mathrm{~d}$ & $73.7 \mathrm{~d}$ & $73.1 \mathrm{~d}$ & $72.7 \mathrm{~d}$ & $73.4 \mathrm{~d}$ & $73.4 \mathrm{~d}$ \\
\hline 17 & $59.6 \mathrm{~d}$ & $58.2 \mathrm{~d}$ & $58.1 \mathrm{~d}$ & $55.0 \mathrm{~d}$ & $58.5 \mathrm{~d}$ & $59.7 \mathrm{~d}$ & $59.9 \mathrm{~d}$ & $54.9 \mathrm{~d}$ & $54.9 \mathrm{~d}$ \\
\hline 18 & $17.1 \mathrm{q}$ & $16.8 \mathrm{q}$ & $16.9 \mathrm{q}$ & $10.5 \mathrm{q}$ & $17.0 \mathrm{q}$ & $17.0 \mathrm{q}$ & $17.4 \mathrm{q}$ & $10.5 \mathrm{q}$ & $10.5 \mathrm{q}$ \\
\hline 19 & $24.3 \mathrm{q}$ & $22.4 \mathrm{q}$ & $22.7 \mathrm{q}$ & $22.7 \mathrm{q}$ & $23.2 \mathrm{q}$ & $23.8 \mathrm{q}$ & $23.8 \mathrm{q}$ & $22.8 \mathrm{q}$ & $23.7 \mathrm{q}$ \\
\hline 20 & $173.8 \mathrm{~s}$ & $169.9 \mathrm{~s}$ & $168.8 \mathrm{~s}$ & $173.1 \mathrm{~s}$ & $169.0 \mathrm{~s}$ & $173.7 \mathrm{~s}$ & $173.0 \mathrm{~s}$ & $173.2 \mathrm{~s}$ & $173.3 \mathrm{~s}$ \\
\hline 21 & $77.9 \mathrm{t}$ & $75.9 \mathrm{t}$ & $75.7 \mathrm{t}$ & $77.7 \mathrm{t}$ & $75.6 \mathrm{t}$ & $77.9 \mathrm{t}$ & $77.2 \mathrm{t}$ & $77.7 \mathrm{t}$ & $77.7 \mathrm{t}$ \\
\hline 22 & $120.6 \mathrm{~d}$ & $119.5 \mathrm{~d}$ & $120.0 \mathrm{~d}$ & $120.7 \mathrm{~d}$ & $119.7 \mathrm{~d}$ & $120.6 \mathrm{~d}$ & $120.5 \mathrm{~d}$ & $120.6 \mathrm{~d}$ & $120.6 \mathrm{~d}$ \\
\hline 23 & $177.3 \mathrm{~s}$ & $175.3 \mathrm{~s}$ & $174.5 \mathrm{~s}$ & $177.5 \mathrm{~s}$ & $174.7 \mathrm{~s}$ & $177.4 \mathrm{~s}$ & $175.1 \mathrm{~s}$ & $177.6 \mathrm{~s}$ & $177.4 \mathrm{~s}$ \\
\hline 3-O-Me & - & - & - & - & $\begin{array}{l}47.7 \mathrm{q} \\
(\times 2)\end{array}$ & - & - & - & - \\
\hline
\end{tabular}
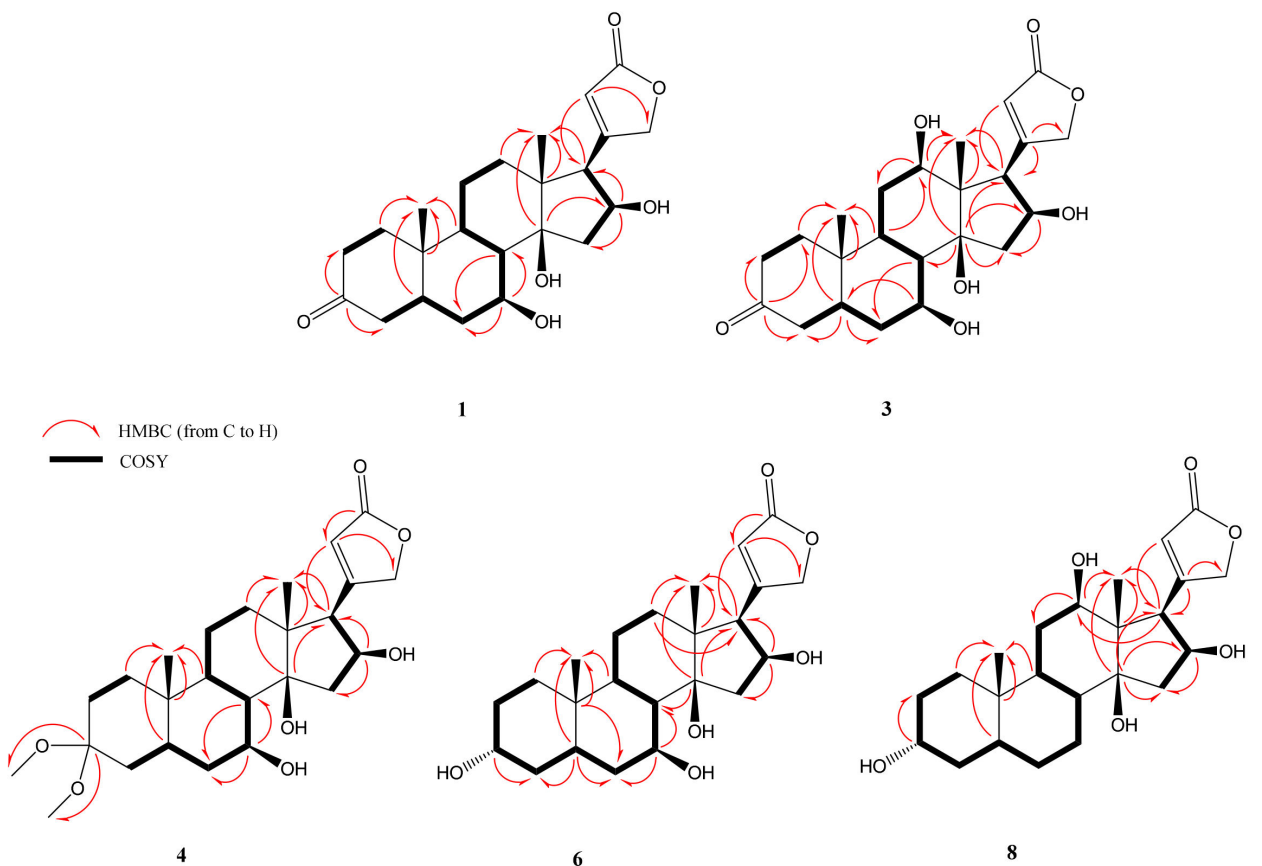

Figure 3. Key HMBC and COSY correlations of the new metabolites (compounds 1, 3, 4, 6 and 8) obtained from the microbial biotransformation of gitoxigenin by A. eureka 1E1BL1.

The molecular formula of 2 was determined as $\mathrm{C}_{23} \mathrm{H}_{32} \mathrm{O}_{5}$ based on the HR-ESI-MS analysis $\left(m / z 433.2227[\mathrm{M}+\mathrm{FA}-\mathrm{H}]^{-}\right.$, calcd. 433.2231 for $\left.\mathrm{C}_{23} \mathrm{H}_{32} \mathrm{O}_{5}\right)$ with eight indices of 
hydrogen deficiency (HD). Apart from the absence of hydroxymethine signal of C-3 and the downfield shift of carbon resonances belonging to A-ring, the characteristic signals of the gitoxigenin were present for 2 . In the ${ }^{13} \mathrm{C}-\mathrm{NMR}$ spectrum, the resonance at $\delta_{\mathrm{C}}$ 212.7 was evident for modification of $\mathrm{C}-3$ secondary alcohol to a ketone, substantiating the increase in HD. Moreover, the HMBC correlations of C-3 with one of $\mathrm{H}_{2}-2\left(\delta_{\mathrm{H}} 2.32\right.$, dd, $J=14.5 ; 6.4 \mathrm{~Hz})$ and $\mathrm{H}_{2}-4\left(\delta_{\mathrm{H}} 2.62 \mathrm{~m}\right)$ resonances, justified the oxidation at C-3 (Figure 4). Consequently, compound 2 was established as 3-oxo-gitoxigenin, a previously identified compound [34,35].

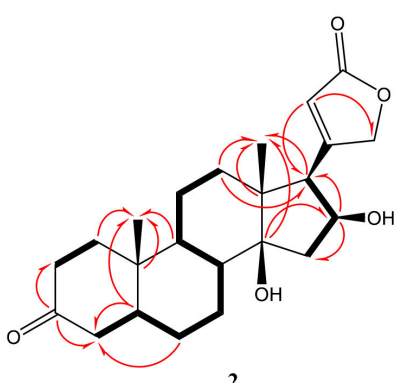

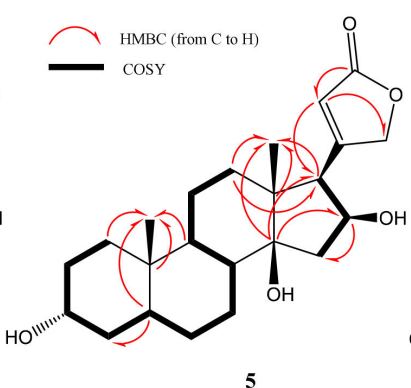

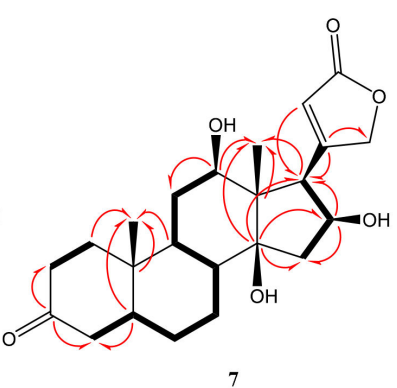

7

Figure 4. Key HMBC and COSY correlations of the known metabolites (compounds 2, 5 and 7) obtained from the microbial biotransformation of gitoxigenin by A. eureka 1E1BL1.

The HR-ESI-MS spectrum of 3 showed a major ion peak at $m / z 419.2075$ (calcd. 419.2075 for $\mathrm{C}_{23} \mathrm{H}_{32} \mathrm{O}_{7}[\mathrm{M}-\mathrm{H}]^{-}$) indicating a molecular formula of $\mathrm{C}_{23} \mathrm{H}_{32} \mathrm{O}_{7}$. The disappearance of the oxymethine signal of $\mathrm{C}-3$ and the presence of a carbonyl carbon signal at $\delta_{C} 214.5$ implied a similar modification, as in $\mathbf{1}$ and 2. Examination of the HMBC spectra proved oxidation at $\mathrm{C}-3$. In the spectrum, two additional low-field resonances $\left(\delta_{\mathrm{H}} 3.91\right.$ and $\delta_{\mathrm{H}}$ 3.36) were observed. Besides, two extra down-field carbon signals at $\delta 70.3$ and $\delta 75.9$ were also noted. In order to deduce the oxygenation positions, the 2D NMR spectra were studied thoroughly. Like 1, a monooxygenation at C-7 was confirmed via inspection of the COSY spectrum $\left(\mathrm{H}-7: \delta_{\mathrm{H}} 3.91\right)$. The second hydroxy group was located at $\mathrm{C}-12$ on the basis of the HMBC spectrum, which showed a cross-peak between the $C-12\left(\delta_{C} 75.9\right)$ signal and $\mathrm{H}-18\left(\delta_{\mathrm{H}} 0.89 \mathrm{~s}\right)$. The relative orientations of hydroxy groups at C-7 and C-12 were determined based on the 2D-NOESY data. The $\mathrm{H}-12\left(\delta_{\mathrm{H}} 3.36\right.$, dd $\left.J=11.8,4.1 \mathrm{~Hz}\right)$ signal showed NOE correlation with $\alpha$-oriented $\mathrm{H}-17\left(\delta_{\mathrm{H}} 3.58, \mathrm{~d}, J=7.6 \mathrm{~Hz}\right)$ verifying the orientation of C-12 hydroxy as $\beta$. Likewise, based on the NOE correlation observed between $\mathrm{H}-7$ ( $\delta_{\mathrm{H}} 3.91$, $\operatorname{td} J=11.6 ; 11.2 ; 4.7 \mathrm{~Hz})$ and $\alpha$-oriented $\mathrm{H}-9\left(\delta_{\mathrm{H}} 1.88, \mathrm{~m}\right), \mathrm{C}-7$ hydroxy group was deduced as $\beta$-oriented. Finally, the structure of 3 was assigned as $7 \beta, 12 \beta$-dihdyroxy-3-oxo-gitoxigenin.

The molecular formula of 4 was found to be $\mathrm{C}_{25} \mathrm{H}_{38} \mathrm{O}_{7}$ based on the major ion peak at $m / z 449.2541[\mathrm{M}-\mathrm{H}]^{-}$(calcd. 449.2545 for $\mathrm{C}_{25} \mathrm{H}_{38} \mathrm{O}_{7}[\mathrm{M}-\mathrm{H}]^{-}$). Inspection of the ${ }^{1} \mathrm{H}-\mathrm{NMR}$ spectrum of 4 showed two $O$-methyl groups $\left(\delta_{\mathrm{H}} 3.12\right.$ and $\left.\delta_{\mathrm{H}} 3.19\right)$ corresponding to the same carbon resonance $\left(\delta_{C} 47.7\right)$ in the HSQC spectrum suggesting a geminal dimethoxy substitution. Based on the absence of a low-field oxymethine signal due to $\mathrm{H}-3$ in the ${ }^{1} \mathrm{H}-\mathrm{NMR}$ spectrum, and the observation of a new quaternary signal $\left(\delta_{\mathrm{C}} 100.4\right)$ displaying long-range correlations with $\delta_{\mathrm{H}} 3.12$ and $\delta_{\mathrm{H}} 3.19$ signals in the $\mathrm{HMBC}$ spectrum, a geminal dimethoxy substitution at C-3 was deduced unambiguously. An additional low-field proton signal was also present at $\delta_{\mathrm{H}} 3.96$ indicating an oxymethine group in the structure. Examination of the COSY and HSQC spectra suggested the monooxygenation position to be $\mathrm{C}-7$, as in 3 . This assumption was confirmed by the HMBC experiment, which showed the long-range correlations from $\mathrm{H}_{2}-6\left(\delta_{\mathrm{H}} 1.57\right.$ and 1.92) and $\mathrm{H}-8\left(\delta_{\mathrm{H}} 1.72\right)$ to the $70.9 \mathrm{ppm}$ resonance (C-7). The stereochemistry of the hydroxy group at C-7 was established via 2D-NOESY spectrum. The observed cross peaks from $\mathrm{H}-7\left(\delta_{\mathrm{H}} 3.96, \mathrm{~m}\right)$ to $\alpha$-oriented protons $\mathrm{H}-9\left(\delta_{\mathrm{H}} 1.54, \mathrm{~m}\right)$ and $\mathrm{H}-17\left(\delta_{\mathrm{H}} 2.91, \mathrm{dd}, J=7.0 ; 3.0 \mathrm{~Hz}\right)$ substantiated the orientation of $\mathrm{C}-7$ hydroxy as $\beta$. Based on this evidence, the structure of 4 was determined as 3-dimethylacetal-7 $\beta$-hydroxygitoxigenin. 
Compound 5 was identified as 3-epigitoxigenin by comparison of the spectroscopic data with those previously reported by Kawaguchi et al. [36].

The major peak at $m / z 405.2280[\mathrm{M}-\mathrm{H}]^{-}$(calcd. 405.2283 for $\mathrm{C}_{23} \mathrm{H}_{34} \mathrm{O}_{6}[\mathrm{M}-\mathrm{H}]^{-}$) in the HR-ESI-MS spectrum of compound 6 indicated $16 \mathrm{amu}$ increase over gitoxigenin and 5 (3-epi-gitoxigenin), implying a hydroxylated analogue of either of them. The ${ }^{1} \mathrm{H}$ and ${ }^{13} \mathrm{C}-\mathrm{NMR}$ spectra of 6 were found to be very similar to those of 5 , except for an additional proton at $\delta_{\mathrm{H}} 4.26$ corresponding to a carbon signal at $\delta_{\mathrm{C}} 70.5$ in the HSQC spectrum (Tables 1 and 2). In the COSY spectrum, the spin system starting from the $\mathrm{H}-8$ $\left(\delta_{\mathrm{H}} 1.95, \mathrm{~m}\right) / \mathrm{H}-7\left(\delta_{\mathrm{H}} 4.26, \mathrm{~m}\right) / \mathrm{H}_{2}-6\left(\delta_{\mathrm{H}} 1.80, \mathrm{~m}\right.$ and $\left.2.14 \mathrm{td}, J=12.2,4.9 \mathrm{~Hz}\right)$, together with the long-range correlations from $\mathrm{C}-7\left(\delta_{\mathrm{C}} 70.5\right)$ to $\mathrm{H}_{2}-6$ and $\mathrm{H}-8$ in the $\mathrm{HMBC}$ spectrum (see Figure 3) helped us to determine the location of hydroxylation as C-7. The relative configuration of C-7 was clarified via the interpretation of 2D-NOESY spectrum which indicated a correlation between $\alpha$-oriented $\mathrm{H}-16\left(\delta_{\mathrm{H}} 4.94, \mathrm{~m}\right)$ and one of $\mathrm{H}-15$ protons appeared at $\delta_{\mathrm{H}}$ 2.67. In turn, the cross peak from $\alpha$-oriented $\mathrm{H}-15\left(\delta_{\mathrm{H}} 2.67, \mathrm{~m}\right)$ to $\mathrm{H}-7\left(\delta_{\mathrm{H}}\right.$ $4.26, \mathrm{~m}$ ) confirmed the orientation of hydroxy group on C-7 as $\beta$. Additionally, the cross peak from $\mathrm{H}-3\left(\delta_{\mathrm{H}} 3.85, \mathrm{~m}\right)$ to $\beta$-oriented $\mathrm{H}-5\left(\delta_{\mathrm{H}} 1.51, \mathrm{~m}\right)$ in the 2D-NOESY spectrum was evident to verify the epimerization at C-3. Consequently, the structure of 6 was elucidated as $7 \beta$-hydroxy-3-epi-gitoxigenin.

In the HR-ESI-MS of 7, the major ion peak was observed at $m / z 449.2179$ [M + FA$\mathrm{H}]^{-}$(calcd. 449.2181 for $\mathrm{C}_{23} \mathrm{H}_{32} \mathrm{O}_{6}[\mathrm{M}+\mathrm{FA}-\mathrm{H}]^{-}$), indicating the same molecular weight with that of $\mathbf{1}$. The presence of characteristic carbonyl carbon signal of C-3 ketone and appearance of a downfield proton resonance at $\delta_{\mathrm{H}} 3.40$ (see Tables 1 and 2), corresponding to $\delta_{C} 76.3$ signal in the HSQC spectrum, implied a monooxygenation in addition to ketone formation on the cardenolide framework. In the HMBC spectrum, key cross peaks from the carbon at $\delta_{\mathrm{C}} 76.3$ to $\mathrm{H}_{2}-11\left(\delta_{\mathrm{H}} 1.30, \mathrm{~m} ; 1.66, \mathrm{~m}\right)$ and $\mathrm{H}_{3}-18\left(\delta_{\mathrm{H}} 0.89, \mathrm{~s}\right)$ helped us to determine the location of hydroxy group as $\mathrm{C}-12$. The relative configuration of $\mathrm{C}-12$ was established via 2D-NOESY data. The strong correlation between $\mathrm{H}-12\left(\delta_{\mathrm{H}} 3.40, \mathrm{dd}, J=11.8\right.$, $4.1 \mathrm{~Hz})$ and $\alpha$ - oriented $\mathrm{H}-17\left(\delta_{\mathrm{H}} 3.59 \mathrm{~d}, J=7.6 \mathrm{~Hz}\right)$, was evident to establish the orientation of $\mathrm{C}-12(\mathrm{OH})$ as $\beta$. On the basis of these evidence, 7 was identified as 3-oxo-diginatigenin, a known compound [37].

The HR-ESI-MS spectrum of compound 8 provided a major ion peak at $m / z 405.2280$ $[\mathrm{M}-\mathrm{H}]^{-}$(calcd. 405.2355 for $\mathrm{C}_{23} \mathrm{H}_{34} \mathrm{O}_{6}[\mathrm{M}-\mathrm{H}]^{-}$), indicating $16 \mathrm{amu}$ increase over gitoxigenin and 5 (3-epi-gitoxigenin). The ${ }^{1} \mathrm{H}$ - and ${ }^{13} \mathrm{C}$-NMR spectra of 8 showed substantial resemblance with those of 5 rather than of gitoxigenin (Tables 1 and 2). The ${ }^{1} \mathrm{H}-\mathrm{NMR}$ spectrum of 8 , in addition to the characteristic low-field signals of 5 , an additional resonance at $\delta_{\mathrm{H}} 3.34$ was observed. In the ${ }^{13} \mathrm{C}-\mathrm{NMR}$ spectrum, the additional oxymethine signal at $\delta_{\mathrm{C}}$ 76.6 undoubtedly demonstrated monohydroxylation on the skeleton, while a key HMBC between the new oxymethine carbon signal and $\mathrm{H}_{3}-18\left(\delta_{\mathrm{H}} 0.87\right.$, s) helped us locating the hydroxy group at C-12. In the NOESY spectrum, $\mathrm{H}-12\left(\delta_{\mathrm{H}} 3.34, \mathrm{~m}\right)$ showed correlation with $\alpha$-oriented $\mathrm{H}-16\left(\delta_{\mathrm{H}} 4.60, \mathrm{td}, J=7.6,1.7 \mathrm{~Hz}\right)$, establishing the orientation of $\mathrm{OH}-12$ as $\beta$. Also, the NOESY correlation between $\mathrm{H}-3\left(\delta_{\mathrm{H}} 3.59, \mathrm{~m}\right)$ and $\beta$-oriented $\mathrm{H}-5\left(\delta_{\mathrm{H}} 1.45, \mathrm{~m}\right)$ verified the epimerization at $\mathrm{C}-3$ indicating $\alpha$-orientation of $\mathrm{C}-3(\mathrm{OH})$. In conclusion, the structure of $\mathbf{8}$ was elucidated as 3-epi-diginatigenin.

The microbial biotransformation study on gitoxigenin afforded five new cardenolide derivatives $1,3,4,6$ and 8 together with 3 previously identified compounds 2,5 and 7 . The structures and approximate yields were illustrated in Figure 5. 


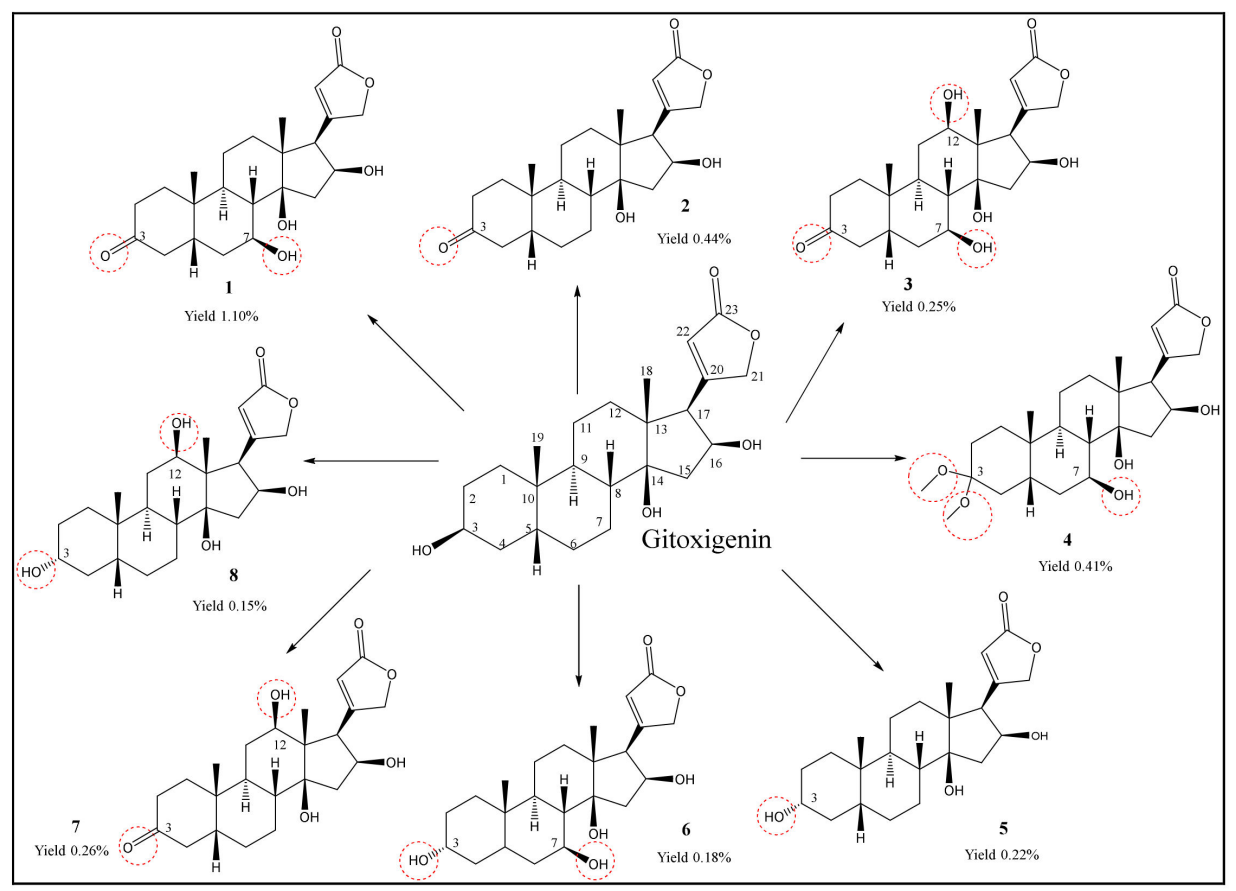

Figure 5. Structures and yields of the metabolites obtained via microbial biotransformation of gitoxigenin by A. eureka 1E1BL1.

Structurally, the 3-oxo metabolites of gitoxigenin 1-3 and $\mathbf{7}$ were mainly obtained. The formation of 3-oxogitoxigenin by Gibberella fujikuroi and Fusarium sp. was demonstrated in earlier biotransformation studies [34,36-38]. The structure was determined using paper partition chromatography, IR and Kedde's color reaction; however, NMR-based structural characterization was absent. Also, absorption spectroscopy analysis of gitoxigenin and 3-oxo-gitoxigenin was reported with a series of related cardenolides. Likewise, other known 3-keto derivative 3-oxodiginatigenin (7), was fermentatively prepared from diginatigenin previously by Repke and Klesczewski; however, limited spectroscopic data was available [37]. Thus, in this study, $\mathbf{2}$ and $\mathbf{7}$ were characterized thoroughly based on the NMR data for the first time.

Compounds 5, $\mathbf{6}$ and $\mathbf{8}$ were 3 -epi derivatives of gitoxigenin. Similar epimerization metabolites were earlier reported in independent biotransformation and semi-synthesis studies [36-39]. Moreover, Repke and Samuels carried out an in vitro study with liver tissue preparations from rats using digitoxigenin as substrate to examine the enzymatic foundation of C-3 epimerization [40]. It was pointed out that the epimerization process of cardiac steroids involved two stages: first, oxidation of the substrate by diphosphopyridine nucleotide (DPN)-dependent $3 \beta$-hydroxy steroid dehydrogenases; second, reduction of the 3 -keto intermediate by the triphosphopyridine nucleotide (TPN)-dependent $3 \alpha$-hydroxy steroid dehydrogenases. Also, Hennebert et al. carried out docking experiments on steroids with intention to explain the epimerization mechanism of dehydrogenases [41]. Considering the earlier reports and the formation of 3-keto metabolites chiefly in this study, it is rational to state that the 3-epi derivatives are likely to be originated via 3-keto intermediates by $3 \alpha$-hydroxy dehydrogenases.

Finally, compound 4 exhibited an unusual structure with dimethyl acetal functionality at C-3 reported here for the first time. Previously, 3,3-dimethoxy analogs of two cardenolides (uzarigenin and digitoxigenin) were prepared via semi-synthesis [42]. It is known that aldehydes and ketones in acidic environment with the presence of methanol can form dimethyl acetals. To make sure that 4 is not an artefact, LC-MS analyses were performed for the samples of Day 6, 10, 14, 18 and the final ethyl acetate (EtOAc) extract (Day 21) used for isolation studies (see chromatograms S10 and S11 in the Supplementary Material). In these experiments, the extracts were treated with neither acids nor methanol. Since 
compound 4 was detected in the last three time points (Day 14, 18 and 21), the formation of dimethyl acetal was suggested to take place via biocatalysis. One plausible path for acetal formation is P450 monoxygenase catalyzed geminal-diol formation at C-3. Accordingly, Bell-Parikh and Guengerich demonstrated a slow oxidation reaction of ethanol to acetic acid by human P450 2E1 and showed that gem-diol could be formed as an intermediate within the reaction catalyzed via monooxygenation [43]. In another study, gem-diol formation was catalyzed by CYP112, a bacterial P450 monooxygenase, as a part of microbial gibberellin synthesis [44]. Based on the abovementioned research, a plausible stepwise mechanism for acetal formation on the cardenolide core is put forward to be catalyzed by P450 monooxygenases (Figure 6).

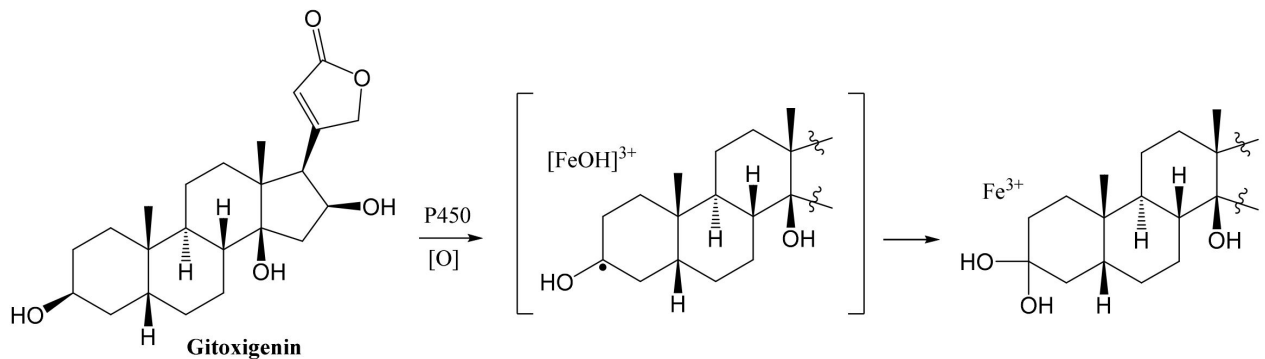

Figure 6. A plausible path for the formation of acetal group in 4 .

Regarding hydroxylation, the monooxygenation took place only on the $\beta$ face of the steroid nucleus involving C-7 (1, 3, 4 and 6) and C-12 (7 and 8) positions (Figure 6). In other words, stereoselective monooxygenations were afforded by $A$. eureka endophyte on the cardenolide skeleton. Most metabolites were monohydroxylated derivatives, whereas the only dihydroxy product was compound 3.

Monooxygenations on the positions of C-7 and C-12 are frequently observed on cardenolides [45]. Diginatigenin, also known as $12 \beta$-hydroxygitoxigenin, was reported first by Murphy, as the aglycone of a cardiac glycoside diginatin isolated from Digitalis lanata [46,47], and later Titus et al. isolated the compound as a biotransformation product of gitoxigenin by Fusarium lini, reconfirming the structure [28]. Our biotransformation studies on gitoxigenin by A. eureka yielded isolation of 3-epi analog of diginatigenin (8, 3-epi-diginatigenin), a previously unidentified compound.

Understanding the metabolism of drugs is vital for preclinical and clinical phases of drug discovery processes being one of the most important factors affecting efficacy/safety rate. Cardenolides, for this purpose, were subjects of several microbial transformation studies, in which some oxidized metabolites were reported as tentative mammalian metabolites. Repke et al. performed an investigation on animal metabolites of digitoxin. After intravenous administration of digitoxin into rats, urinary and fecal sampling for $48 \mathrm{~h}$ led to the isolation of ten compounds, mainly exerting hydrolysis of the glycosidic bonds and $12 \beta$ hydroxylations [37]. Another study was performed on humans by Ashley et al. through digitoxin administration per os, and $12 \beta$-hydroxylated metabolites were determined in urine samples [48]. Our findings were consistent with both of these studies representing $12 \beta$-hydroxy metabolites.

\subsection{MTT Cell Viability Assay}

Cytotoxicity of the metabolites and substrate were evaluated in various cancer cell lines (pancreatic: PANC-1, MIA PaCa-2; prostate: DU 145 and lung: A549) and two healthy cell lines (lung: MRC-5 and kidney: HEK-293) by MTT cell viability assay (Table 3). 
Table 3. Cytotoxic activities of compounds 1-8 and the substrate gitoxigenin.

\begin{tabular}{|c|c|c|c|c|c|c|}
\hline Compound & A549 & DU 145 & PANC-1 & MIA PaCa-2 & HEK-293 & MRC-5 \\
\hline 1 & $>10$ & $>10$ & $>10$ & $>10$ & $>10$ & $>10$ \\
\hline 2 & $>10$ & $>10$ & $>10$ & $>10$ & $>10$ & $>10$ \\
\hline 3 & $>10$ & $>10$ & $>10$ & $>10$ & $>10$ & $>10$ \\
\hline 4 & $>10$ & $>10$ & $>10$ & $>10$ & $>10$ & $>10$ \\
\hline 5 & $>10$ & $>10$ & $>10$ & $>10$ & $>10$ & $>10$ \\
\hline 6 & $>10$ & $>10$ & $>10$ & $>10$ & $>10$ & $>10$ \\
\hline 7 & $>10$ & $>10$ & 6.24 & $>10$ & $>10$ & $>10$ \\
\hline 8 & 8.25 & $>10$ & 1.95 & 3.4 & $>10$ & 9.35 \\
\hline Gitoxigenin & 2.19 & 4.08 & 1.53 & 3.1 & 7.6 & 0.815 \\
\hline Oleandrin & 0.0426 & 0.0210 & 0.0387 & 0.0350 & 0.0730 & 0.0173 \\
\hline Doxorubicin & 0.6200 & 0.1900 & $>10$ & 0.5900 & 0.5870 & 0.8650 \\
\hline
\end{tabular}

$\mathrm{IC}_{50}$ values are the concentration $(\mu \mathrm{M})$ required $50 \%$ cell viability inhibition for a given compound with a $48 \mathrm{~h}$ treatment and were calculated with using cell viability (\%) formula via nonlinear regression analysis. Experiment was carried out in triplicate $(n=3)$. IC 50 values were given for A549 human lung cancer cell line, DU 145 human prostate cancer cell line, PANC-1 human pancreatic cancer cell line, Mia PaCa-2 pancreatic cancer cell line. HEK-293 human embryonic kidney cell line and MRC-5 human lung fibroblast cell line as healthy cell lines. Doxorubicin and oleandrin were used as positive controls.

Compound 7 (3-oxodiginatigenin) exhibited cytotoxic activity against PANC-1 with an $\mathrm{IC}_{50}$ value of $6.24 \mu \mathrm{M}$, while 3-epidiginatigenin (8) demonstrated higher bioactivity against PANC-1, A549, and MIA PaCa-2 with 1.95, 8.25 and $3.4 \mu \mathrm{M} \mathrm{IC}_{50}$ values, respectively. These findings suggested that $12 \beta$-monohydroxylated derivatives 7 and 8 of gitoxigenin had higher cytotoxicity especially on PANC-1 cell line compared to the other metabolites.

Although, the $\mathrm{IC}_{50}$ values of $\mathbf{8}$ for cancer cell lines were higher than the substrate and the control groups (oleandrin and doxorubicin), slighter cytotoxic effect was observed for healthy cell lines. Therefore, the new compound 8 could be evaluated further because of its better therapeutic index and probably enhanced bioavailability.

Gitoxigenin was recently investigated for its cytotoxic activity against human cancer cell lines; TK-10 (renal adenocarcinoma), UACC-62 (melanoma) and MCF-7 (breast adenocarcinoma), and the $\mathrm{IC}_{50}$ values were reported as $0.415 \pm 0.03,2.83 \pm 0.17$ and $1.80 \pm 0.32 \mu \mathrm{M}$, respectively [21]. The growth inhibitory effect of gitoxigenin on HeLa cells was also reported as $2.25 \mu \mathrm{g} / \mathrm{mL}$ [49], while in vitro inhibitory activity against human nasopharynx carcinoma was presented with an $\mathrm{ED}_{50}$ value of $2.3 \mu \mathrm{g} / \mathrm{mL}$ [50]. According to our results, gitoxigenin exhibited cytotoxic activity against A549, DU 145, PANC-1, MIA $\mathrm{PaCa}-2$ cell lines with $\mathrm{IC}_{50}$ values ranging between 1.53 and $4.08 \mu \mathrm{M}$.

From the structure activity relationship perspective, as the C-3 epimers of gitoxigenin have reduced cytotoxicity, one can state that the configuration of $\mathrm{C}-3$ ( $\beta$-oriented $\mathrm{OH}$ group), as in gitoxigenin, seems important for higher bioactivity. Furthermore, less toxic biotransformation products obtained within this study point out to possible intermediates of detoxification mechanism for gitoxigenin.

Consequently, biotransformation attracts interest because of its advantages, viz. higher specificity and efficiency. This study shows that $A$. eureka 1E1BL1 is a good choice for the biotransformation of cardenolides. As incubation with a specific microorganism can replace a series of reaction steps in chemical synthesis, findings presented here may offer a biotechnological alternative to perform regio- and stereo-selective reactions. Furthermore, the functional enzymes responsible for $C-12 \beta$ and $C-7 \beta$ stereoselective hydroxylations, C-3 epimerization, C-3 oxidation or dimethyl acetal formation reactions on cardenolides, might be isolated from A. eureka and then be used as biocatalysts in metabolite engineering processes with the purpose of decreasing the cost of downstream processing.

\section{Materials and Methods}

\subsection{General Experimental Procedures}

Column chromatography studies were carried out using silica gel 60 (70-230 mesh, Merck, Darmstadt, Germany) and LiChroprep ${ }^{\circledR}$ RP-C18 (25-40 $\mu \mathrm{m}$ particle size, Merck) 
as adsorbents. A medium-pressure pump was used for vacuum liquid chromatography (VLC) while $\mathrm{RP}_{-} \mathrm{C}_{18}$ column chromatography was accompanied by a peristaltic pump. Analytical thin layer chromatography (TLC) was carried out on pre-coated silica gel $60 \mathrm{~F}_{254}$ or RP- $\mathrm{C}_{18} \mathrm{~F}_{254}$ aluminium plates ( $20 \times 20 \mathrm{~cm}$, layer thickness $0.2 \mathrm{~mm}$, Merck). All isolation and purification steps have been checked by TLC plates on which spots were visualised by spraying with $20 \%$ sulphuric acid in water and then heated at $105^{\circ} \mathrm{C}$ until visualized under day light and examined under UV light (254 and $365 \mathrm{~nm}$ ). Mass spectrometry analysis were carried out on an Agilent 1200/6530 HR-ESI-MS instrument (Agilent Technologies, Inc., Santa Clara, CA USA) in positive and negative modes. The LC-MS analysis was performed on an Agilent 1260 Series HPLC system coupled with an Agilent G6550A iFunnel Quadrupole Time-of-Flight with a Dual Spray Agilent Jet Stream electrospray ionisation source (Agilent Technologies, Inc.). The instrument was operated in $2 \mathrm{GHz}$ Extended Dynamic Range mode with negative electrospray ionisation. The separation was performed on a reversed phase Agilent Zorbax Extend column $(4.6 \mathrm{~mm} \times 150 \mathrm{~mm}$ $\times 3.5 \mu \mathrm{m})$. The data was processed by Agilent MassHunter software B 06.00. 1D-, 2DNMR spectra were recorded on a Varian AS 400 Mercury NMR spectrometer (Varian, Palo Alto, CA, USA) and a Bruker DRX 500 (Bruker Biospin, Silberstreifen 4, Rheinstetten, Germany). ${ }^{1} \mathrm{H}$-NMR spectra were recorded at $400 / 500 \mathrm{MHz}$, and the chemical shifts were reported in units of parts per million (ppm) relative to the solvent peaks $\left(\mathrm{CDCl}_{3}: \delta=7.26\right.$, $\mathrm{CD}_{3} \mathrm{OD}: \delta=3.33 \mathrm{ppm}$ or pyridine- $d_{5}: \delta=8.74 ; 7.58$ and $7.22 \mathrm{ppm}$ ). ${ }^{13} \mathrm{C}-\mathrm{NMR}$ spectra were recorded at $100 \mathrm{MHz}$, and the chemical shifts were reported in ppm relative to the solvent peaks $\left(\mathrm{CDCl}_{3}: \delta=77.0, \mathrm{CD}_{3} \mathrm{OD}: 49.0 \mathrm{ppm}\right.$ or pyridine- $d_{5}: 150.4 ; 135.9$ and $\left.123.9 \mathrm{ppm}\right)$. FT-IR (Fourier transform infrared) spectroscopic data were collected on a Perkin-Elmer Spectrum 100 FT-IR Spectrometer (Perkin Elmer, Wellesley, MA, USA). Optical rotations were measured in methanol using a AutoPol I polarimeter (Rudolph Research Analytical, 55 Newburgh Road Hackettstown, NJ, USA) at $18^{\circ} \mathrm{C}$.

\subsection{Plant Material}

Nerium oleander L. was harvested from Urla (Izmir, Turkey) in Nov $2019\left(38^{\circ} 19^{\prime} 09.4^{\prime \prime} \mathrm{N}\right.$ $26^{\circ} 38^{\prime} 35.5^{\prime \prime}$ E). The plant material was identified by Prof. Dr. Erdal BEDİR (Department of Bioengineering, IZTECH, Izmir, Turkey) and a voucher specimen is deposited at the Herbarium of the Department of Pharmacognosy, Faculty of Pharmacy, Ege University, Izmir, Turkey with the herbarium number of 1640.

\subsection{Preparation of Gitoxigenin, the Substrate, by Acid-Catalysed Hydrolysis of Oleandrin}

In the context of this study, oleandrin, which was recently isolated from dried leaves of $N$. oleander according to a modified method of Ryer et al. [51] by our research team [33], has been used as the main starting compound.

An acid-catalysed hydrolysis reaction of oleandrin was performed in order to obtain gitoxigenin. Briefly, $4 \mathrm{~g}$ of oleandrin was dissolved in $1500 \mathrm{~mL}$ of $2 \mathrm{~N}$ trifluoroacetic acid (TFA) in $n$-butanol and stirred at $200{ }^{\circ} \mathrm{C}$ for 90 min under reflux. Hydrolysis was carried out in four portions (1g oleandrin in $375 \mathrm{~mL} 2 \mathrm{~N}$ TFA in $n$-butanol per each). The progression of the reaction was checked by TLC (Mobile system: 97:3 chloroform: methanol) at every $30 \mathrm{~min}$. At the end of $90 \mathrm{~min}$, the reaction was ended neutralizing with $4 \mathrm{~N} \mathrm{KOH}$ in water. Neutral reaction mixture was partitioned between chloroform and water in order to remove salt and other inorganic impurities. Chloroform was evaporated at $40{ }^{\circ} \mathrm{C}$ and the organic residue (12.2 g) was loaded onto a silica gel column using a gradient system of chloroform: isopropanol (100:0 to 95:5) to afford 80 fractions. Gitoxigenin with slight impurities was obtained from the collected fractions of 51-72. Further purification was achieved by precipitation of Fr: 51-72 in acetonitrile (ACN) resulting in high purity gitoxigenin ( $1.05 \mathrm{~g}$, ca. $25 \%$ yield) as a white powder. Structural elucidation of gitoxigenin was carried out by modern spectroscopic techniques (1D, 2D NMR and HR-ESI-MS). 


\subsection{Microbial Biotransformation Procedure}

Biotransformation of gitoxigenin was performed by Astragalus angustifolius-originated endophytic fungus Alternaria eureka 1E1BL1, which was isolated and identified by our group in 2016 [52]. The fungal strain stocks prepared as spore solutions in glycerol were stored at $-80^{\circ} \mathrm{C}$, also potato dextrose agar (PDA) slants prepared and stored at $4{ }^{\circ} \mathrm{C}$ until use. Fungi was grown on potato dextrose agar (PDA) Petri dishes at $25^{\circ} \mathrm{C}$ for 10 days, then spore solution was prepared in $0.1 \%(v / v)$ Tween 80 and used to inoculate $(2 \% v / v)$ five of $5 \mathrm{~L}$ Erlenmeyer flasks containing $1.5 \mathrm{~L}$ of potato dextrose broth (PDB). After incubation for 3 days, $1050 \mathrm{mg}$ of gitoxigenin was added into the flasks, and biotransformation was carried out in a rotary shaker at $180 \mathrm{rpm}, 25^{\circ} \mathrm{C}$ for 21 days. Biotransformation process was followed by checking the ethyl acetate extracts of daily collected samples on TLC plates [29].

\subsection{Isolation and Purification}

After three weeks of biotransformation, fungal biomass was removed by filtering through Whatman No.1 filter paper on Buchner funnel under vacuum, and the broth was extracted three times with equal volume of EtOAc. The organic phase was evaporated by rotary vacuum evaporator at $40^{\circ} \mathrm{C}$.

Initially, the crude EtOAc extract ( $8.7 \mathrm{~g}$ ) was subjected to a silica gel column (175 g) and eluted with a gradient system of $\mathrm{CHCl}_{3}: \mathrm{MeOH}(98: 2,97: 3,95: 5,90: 10)$. Following collection of the main fractions (1-620), similar ones were combined together based on their TLC profiles.

Firstly, the combined fractions of 15-16 (172 mg) were loaded onto an RP-C $\mathrm{C}_{18}(17.5 \mathrm{~g})$ column which was eluted in gradient mode with $\mathrm{H}_{2} \mathrm{O}$ : ACN (70:30 to 60:40) using a VLC system. Subfractions 14-18 were pooled together and precipitated in cold ACN to obtain $\mathbf{1}(11.5 \mathrm{mg})$. The main fraction $14(36.6 \mathrm{mg})$ was applied to a silica gel column $(12 \mathrm{~g})$ and eluted with isocratic $\mathrm{CHCl}_{3}(100 \%)$ yielding $2(4.6 \mathrm{mg})$.

Compound 3 (2.6 mg) was isolated from the combined fractions of 528-572 (22.9 mg), chromatographed over RP-C 18 (17.5 g) by a VLC system using $\mathrm{H}_{2} \mathrm{O}$ : ACN (80:20) for elution. Compound $4(4.3 \mathrm{mg})$ was recovered from the combined fractions of 221-280 $(71.3 \mathrm{mg})$ that was loaded onto a silica gel column $(40 \mathrm{~g})$ and eluted with a gradient system of $\mathrm{CHCl}_{3}: \mathrm{MeOH}(98: 2,97: 3,96: 4,90: 10)$.

The combined fractions of 281-370 (40.4 mg) were applied to a silica gel column $(15.7 \mathrm{~g})$ and eluted with an increasing gradient of $n$-hexane: EtOAc: $\mathrm{MeOH}$ (10:10:0.5 to 10:10:1.5). Subfractions $54-70(14.6 \mathrm{mg})$ was subjected to a sequential fractionation using silica gel $(7 \mathrm{~g})$ as stationary phase and $\mathrm{CHCl}_{3}: \mathrm{MeOH}$ (97:3) as mobile phase to obtain 5 (2.3 mg).

Compounds 6 and 7 were isolated from the main fractions of 393-430 (37.4 mg), which was chromatographed over an RP- $\mathrm{C}_{18}(17.5 \mathrm{~g})$ VLC column and eluted with a gradient system of $\mathrm{H}_{2} \mathrm{O}: \mathrm{ACN}$ (from 80:20 to 20:80). Subfraction 24 was further purified through crystallization in cold ACN yielding $\mathbf{6}(1.9 \mathrm{mg})$, while $\mathbf{7}(2.7 \mathrm{mg})$ was obtained directly from subfraction 22 in pure form. Compound $8(1.6 \mathrm{mg})$ was isolated from the main fractions of 604-619 (5.2 mg), which was fractionated on RP-C 18 (17.5 g) by VLC system using a gradient system of $\mathrm{H}_{2} \mathrm{O}: \mathrm{ACN}$ (from 90:10 to 80:20).

\subsection{Compound Characterization}

4-((3S,5R,10S,13R,14S,16S,17R)-3,14,16-Trihydroxy-10,13-dimethylhexadecahydro-1H-cyclopenta [a]phenanthren-17-yl) furan-2(5H)-one) (gitoxigenin). White powder. FT-IR ( $\left.\mathrm{CHCl}_{3}: \mathrm{MeOH}\right)$ : 3526, 3431, 2942, 2887, 1789, 1759, 1737, 1629, 1451, 1376, 1185, 1093, 1033, $888 \mathrm{~cm}^{-1}$. HRESI-MS (negative ion mode): $\mathrm{m} / z=435.2387$ [M + FA-H] $]^{-}$[Calculated for $\mathrm{C}_{23} \mathrm{H}_{34} \mathrm{O}_{5}[\mathrm{M}+$ FA-H $]^{-}$435.2388]. $[\alpha]_{\mathrm{D}}{ }^{18}=+14.7^{\circ}(\mathrm{c} 0.27, \mathrm{MeOH}) .{ }^{1} \mathrm{H}-\mathrm{NMR}\left(\mathrm{CD}_{3} \mathrm{OD} /\right.$ drops of pyridine- $d_{5}$, $500 \mathrm{MHz})$ : see Table $1 ;{ }^{13} \mathrm{C}-\mathrm{NMR}\left(\mathrm{CD}_{3} \mathrm{OD} /\right.$ drops of pyridine- $\left.d_{5}, 100 \mathrm{MHz}\right)$ : see Table 2. 
(4-((5R,10S,13R,14S,16S,17R)-7,14,16-Trihydroxy-10,13-dimethyl-3-oxohexadecahydro-1Hcyclopenta[a]phenanthren-17-yl)furan-2(5H)-one (7 $\beta$-hydroxy-3-oxo-gitoxigenin, 1). White needles. FT-IR $\left(\mathrm{CHCl}_{3}\right)$ : 3405, 2942, 2873, 2156, 1739, 1712, 1631, 1617, 1449, 1341, 1284 , $1110,1051,1032,755 \mathrm{~cm}^{-1}$. HR-ESI-MS (negative ion mode): $m / z=403.2123[\mathrm{M}-\mathrm{H}]^{-}$ [Calculated for $\left.\mathrm{C}_{23} \mathrm{H}_{32} \mathrm{O}_{6}[\mathrm{M}-\mathrm{H}]^{-} 403.2126\right] .[\alpha]_{\mathrm{D}}{ }^{18}=+20.4^{\circ}$ (c 0.25, MeOH). ${ }^{1} \mathrm{H}-\mathrm{NMR}$ $\left(\mathrm{CDCl}_{3} / 1\right.$ drop of $\left.\mathrm{CD}_{3} \mathrm{OD}, 400 \mathrm{MHz}\right)$ : see Table $1 .{ }^{13} \mathrm{C}-\mathrm{NMR}\left(\mathrm{CDCl}_{3} / 1\right.$ drop of $\mathrm{CD}_{3} \mathrm{OD}$, $100 \mathrm{MHz})$ : see Table 2.

(4-((5R,10S,13R,14S,16S,17R)-14,16-Dihydroxy-10,13-dimethyl-3-oxohexadecahydro-1H-cyclopenta [a]phenanthren-17-yl)furan-2(5H)-one (3-oxogitoxigenin, 2): White crystalline powder. FTIR $\left(\mathrm{CHCl}_{3}\right.$ : MeOH): 3443, 2926, 2863, 1739, 1714, 1615, 1447, 1285, 1109, 1032, $895 \mathrm{~cm}^{-1}$. HR-ESI-MS (negative ion mode): $m / z=433.2227$ [M + FA-H] ${ }^{-}$[Calculated for $\mathrm{C}_{23} \mathrm{H}_{32} \mathrm{O}_{5}$ $[\mathrm{M}+\mathrm{FA}-\mathrm{H}]^{-}{ }^{433.2231]} \cdot[\alpha]_{\mathrm{D}}{ }^{18}=+12.5^{\circ}$ (c 0.4, MeOH). ${ }^{1} \mathrm{H}-\mathrm{NMR}\left(\mathrm{CDCl}_{3}, 400 \mathrm{MHz}\right)$ : see Table $1 .{ }^{13} \mathrm{C}-\mathrm{NMR}\left(\mathrm{CDCl}_{3}, 100 \mathrm{MHz}\right)$ : see Table 2.

(4-((5R,10S,13S,14S,16S,17R)-7,12,14,16-Tetrahydroxy-10,13-dimethyl-3-oxohexadecahydro-1Hcyclopenta[a]phenanthren-17-yl)furan-2(5H)-one (7 $\beta, 12 \beta$-dihdyroxy-3-oxogitoxigenin, 3): Yellowish-white oily substance. FT-IR $\left(\mathrm{CHCl}_{3}\right.$ : $\left.\mathrm{MeOH}\right): 3381,2935,2876,1732,1628$, $1448,1277,1110,1051,1014 \mathrm{~cm}^{-1}$. HR-ESI-MS (negative ion mode): $\mathrm{m} / z=419.2075$ [M $-\mathrm{H}]^{-}$[Calculated for $\left.\mathrm{C}_{23} \mathrm{H}_{32} \mathrm{O}_{7}[\mathrm{M}-\mathrm{H}]^{-} 419.2075\right]$. $[\alpha]_{\mathrm{D}}{ }^{18}=+12.7^{\circ}$ (c 0.24, MeOH). ${ }^{1} \mathrm{H}-\mathrm{NMR}\left(\mathrm{CD}_{3} \mathrm{OD}, 400 \mathrm{MHz}\right)$ : see Table $1 .{ }^{13} \mathrm{C}-\mathrm{NMR}\left(\mathrm{CD}_{3} \mathrm{OD}, 100 \mathrm{MHz}\right)$ : see Table 2.

(4-((5R,10S,13R,14S,16S,17R)-7,14,16-Trihydroxy-3,3-dimethoxy-10,13-dimethylhexadecahydro-1Hcyclopenta[a]phenanthren-17-yl)furan-2(5H)-one (3-dimethylacetal-7 $\beta$-hydroxygitoxigenin, 4): White powder. FT-IR $\left(\mathrm{CHCl}_{3}\right)$ : 3382, 2937, 2874, 1736, 1616, 1450, 1363, 1279, 1178, 1107, $1094,1051,1035,877,755 \mathrm{~cm}^{-1}$. HR-ESI-MS (negative ion mode): $\mathrm{m} / z=449.2541[\mathrm{M}+$ FA-H $]^{-}$[Calculated for $\mathrm{C}_{25} \mathrm{H}_{38} \mathrm{O}_{7}[\mathrm{M}+\mathrm{FA}-\mathrm{H}]^{-}$449.2545]. $[\alpha]_{\mathrm{D}}{ }^{18}=+20^{\circ}$ (c $\left.0.2, \mathrm{MeOH}\right)$. ${ }^{1} \mathrm{H}$ - NMR $\left(\mathrm{CDCl}_{3}, 400 \mathrm{MHz}\right)$ : see Table $1 .{ }^{13} \mathrm{C}-\mathrm{NMR}\left(\mathrm{CDCl}_{3}, 100 \mathrm{MHz}\right)$ : see Table 2.

(4-((3R,5R,10S,13R,14S,16S,17R)-3,14,16-Trihydroxy-10,13-dimethylhexadecahydro-1H-cyclopenta[a] phenanthren-17-yl)furan-2(5H)-one (3-epigitoxigenin, 5): White needles. FT-IR $\left(\mathrm{CHCl}_{3}\right.$ : $\mathrm{MeOH}): 3411,2935,2865,2156,1735,1615,1450,1379,1170,1114,1093,1073,1034 \mathrm{~cm}^{-1}$. HR-ESI-MS (negative ion mode): $m / z=435.2385[\mathrm{M}+\mathrm{FA}-\mathrm{H}]^{-}$[Calculated for $\mathrm{C}_{23} \mathrm{H}_{34} \mathrm{O}_{5}$ $\left.[\mathrm{M}+\mathrm{FA}-\mathrm{H}]^{-} 435.2388\right] .[\alpha]_{\mathrm{D}}{ }^{18}=+9.2^{\circ}(\mathrm{c} 0.11, \mathrm{MeOH}) .{ }^{1} \mathrm{H}-\mathrm{NMR}\left(\mathrm{CD}_{3} \mathrm{OD}, 400 \mathrm{MHz}\right)$ : see Table 1.; ${ }^{13} \mathrm{C}-\mathrm{NMR}\left(\mathrm{CD}_{3} \mathrm{OD}, 100 \mathrm{MHz}\right)$ : see Table 2.

(4-((3R,5S,10S,13R,14S,16S,17R)-3,7,14,16-Tetrahydroxy-10,13-dimethylhexadecahydro-1Hcyclopenta[a]phenanthren-17-yl)furan-2(5H)-one (7 $\beta$-hydroxy-3-epigitoxigenin, 6): White needles. FT-IR $\left(\mathrm{CHCl}_{3}\right.$ : $\left.\mathrm{MeOH}\right)$ : 3391, 2936, 2869, 2156, 1734, 1455, 1177, 1112, 1051, $774 \mathrm{~cm}^{-1}$. HR-ESI-MS (negative ion mode): $m / z=405.2280[\mathrm{M}-\mathrm{H}]^{-}$[Calculated for $^{-}$ $\mathrm{C}_{23} \mathrm{H}_{34} \mathrm{O}_{6}[\mathrm{M}-\mathrm{H}]^{-}$405.2283]. $[\alpha]_{\mathrm{D}}{ }^{18}=+6.9^{\circ}$ (c 0.29, MeOH). ${ }^{1} \mathrm{H}-\mathrm{NMR}$ (pyridine- $\mathrm{d}_{5}$, $400 \mathrm{MHz}$ ): see Table $1 .{ }^{13} \mathrm{C}-\mathrm{NMR}$ (pyridine- $d_{5}, 100 \mathrm{MHz}$ ): see Table 2.

(4-((5R,10S,13S,14S,16S,17R)-12,14,16-Trihydroxy-10,13-dimethyl-3-oxohexadecahydro-1Hcyclopenta[a]phenanthren-17-yl)furan-2(5H)-one (3-oxodiginatigenin, 7): White powder. FT-IR ( $\mathrm{CHCl}_{3}$ : MeOH): 3394, 2924, 2865, 1733, 1713, 1630, 1455, 1287, 1019, $775 \mathrm{~cm}^{-1}$. HR-ESI-MS (negative ion mode): $m / z=449.2179[\mathrm{M}+\mathrm{FA}-\mathrm{H}]^{-}$[Calculated for $\mathrm{C}_{23} \mathrm{H}_{32} \mathrm{O}_{6}$ $\left.[\mathrm{M}+\mathrm{FA}-\mathrm{H}]^{-} 449.2181\right] \cdot[\alpha]_{\mathrm{D}}{ }^{18}=+21.9^{\circ}$ (c 0.09, $\left.\mathrm{MeOH}\right) \cdot{ }^{1} \mathrm{H}-\mathrm{NMR}\left(\mathrm{CD}_{3} \mathrm{OD}, 400 \mathrm{MHz}\right)$ : see Table $1 .{ }^{13} \mathrm{C}$ - NMR $\left(\mathrm{CD}_{3} \mathrm{OD}, 100 \mathrm{MHz}\right)$ : see Table 2.

(4-((3R,5R,10S,13S,14S,16S,17R)-3,12,14,16-Tetrahydroxy-10,13-dimethylhexadecahydro-1Hcyclopenta[a]phenanthren-17-yl)furan-2(5H)-one (3-epidiginatigenin, 8): White powder. FT-IR $\left(\mathrm{CHCl}_{3}\right.$ : MeOH): 3390, 2929, 2863, 1732, 1614, 1559, 1451, 1074, 1035, $1027 \mathrm{~cm}^{-1}$. HRESI-MS (negative ion mode): $m / z=405.2280\left[\mathrm{M}-\mathrm{H}\right.$ ]- [Calculated for $\mathrm{C}_{23} \mathrm{H}_{34} \mathrm{O}_{6}[\mathrm{M}-$ $\mathrm{H}]^{-}$[405.2355]. $[\alpha]_{\mathrm{D}}{ }^{18}=0.0^{\circ}$ (c 0.18, MeOH). ${ }^{1} \mathrm{H}-\mathrm{NMR}\left(\mathrm{CD}_{3} \mathrm{OD}, 400 \mathrm{MHz}\right)$ : see Table 1. ${ }^{13} \mathrm{C}-\mathrm{NMR}\left(\mathrm{CD}_{3} \mathrm{OD}, 100 \mathrm{MHz}\right)$ : see Table 2. 


\subsection{MTT Assay}

To see cytotoxic effects of the obtained metabolites, a standard MTT (3-(4,5-dimethylthiazol2-yl)-2,5-diphenyltetrazolium bromide) cell viability assay was performed on human cancer cell lines PANC-1 (pancreatic, ATCC ${ }^{\circledR}$ CRL-1469 ${ }^{\mathrm{TM}}$ ), MIA PaCa-2 (pancreatic, ATCC ${ }^{\circledR}$ CRL$1420^{\mathrm{TM}}$ ), DU 145 (prostate, ATCC ${ }^{\circledR}$ HTB-81 ${ }^{\mathrm{TM}}$ ) and A549 (lung, ATCC ${ }^{\circledR}$ CCL-185 ${ }^{\mathrm{TM}}$ ) and two healthy cell lines MRC-5 (lung, ATCC ${ }^{\circledR}$ CCL-171 ${ }^{\text {TM}}$ ) and HEK-293 (kidney, ATCC ${ }^{\circledR}$ CRL-1573 ${ }^{\mathrm{TM}}$ ) according to manufacturer's instructions (M2128, Sigma-Aldrich ${ }^{\circledR}$ ). For this

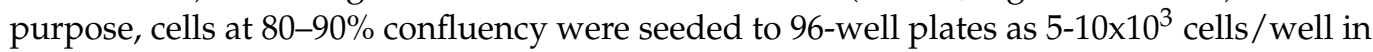
Eagle Minimal Essential Medium (EMEM) or Dulbecco Modified Eagle Medium (DMEM); supplemented with $10 \% \mathrm{FBS}$ and $1 \% \mathrm{~L}$-glutamine depending on the cell type and incubated in a humidified incubator at $37^{\circ} \mathrm{C}$ with $5 \% \mathrm{CO}_{2}$ atmosphere for $24 \mathrm{~h}$. After cell adhesion, gitoxigenin and the metabolites were applied to the cells in triplicate with concentrations ranging between 0.001 and $10 \mu \mathrm{M}$. After $48 \mathrm{~h}$ exposure to certain concentrations of the compounds, medium was replaced with fresh one containing 10\% MTT and plates were incubated for $3 \mathrm{~h}$ in the dark for the conversion of tetrazolium salts to formazan crystals by mitochondrial metabolism of viable cells. After incubation, formazan crystals were dissolved in DMSO and absorbance of each well were measured at $570 \mathrm{~nm}$ via microplate reader (Synergy ${ }^{\mathrm{TM}}$ HTX- BioTek, Winooski, VT, USA). Doxorubicin $(10 \mathrm{nM}, 1 \mu \mathrm{M}$ and $4 \mu \mathrm{M})$ was used as positive control, whereas oleandrin $(1 \mathrm{nM}, 10 \mathrm{nM}$ and $100 \mathrm{nM})$ was the second positive control as a potent cardenolide.

All compounds were dissolved in DMSO (Sigma Aldrich, St. Louis, MO, USA) and the final DMSO concentration applied to cells was $0.02 \%(v / v)$, which is non-toxic to cells. The $\mathrm{IC}_{50}$ values of the compounds were calculated by the normalization of optical densities (OD) to negative control DMSO $(0.02 \%, v / v)$.

Supplementary Materials: The following are available online. Supporting information for structural elucidations (HR-ESI-MS; ${ }^{1} \mathrm{H}$ - and ${ }^{13} \mathrm{C}$-NMR and FT-IR spectroscopic data) of eight biotransformation products (1-8) and substrate gitoxigenin; HPLC and LC-MS chromatograms of selected compounds and crude EtOAc extract of biotransformation broth. Also, the figures of COSY, HSQC and HMBC correlations are available for all compounds.

Author Contributions: Conceptualization and methodology, E.B.; investigation, Ç.K., G.D., G.K. and M.K.; writing—original draft preparation, review and editing, Ç.K., G.D., G.K., M.K., H.Y. and E.B.; supervision, E.B.; project administration, E.B.; resources, H.Y.; funding acquisition, Ç.K. All authors have read and agreed to the published version of the manuscript.

Funding: This research was funded by Türkiye Bilimsel ve Teknolojik Araştırma Kurumu (The Scientific and Technological Research Council of Turkey, TUBITAK) [Grant number 119Z152].

Institutional Review Board Statement: Not applicable.

Informed Consent Statement: Not applicable.

Data Availability Statement: The data presented in this study are available in the text and Supplementary Materials. Raw data will be provided by the corresponding author if requested.

Acknowledgments: This project is financially supported by TUBITAK (project ID: 119Z152). We are thankful to Salih GUNNAZ and Anzarulhaque Anwarulhaque for running NMR experiments, İlhan Gürbüz for helping LC-MS studies, and Derya GÜLCEMAL for assisting optical rotation measurements. We specially thank Eyüp Bilgi and Yiğit Ege Çömlekçi for helping plant collection and Özge Özşen for preliminary experiments.

Conflicts of Interest: The authors declare no conflict of interest.

Sample Availability: Samples of substrate gitoxigenin and compounds (1-8) are available from the authors. 


\section{References}

1. Venisetty, R.; Ciddi, V. Application of microbial biotransformation for the new drug discovery using natural drugs as substrates. Curr. Pharm. Biotechnol. 2003, 4, 153-167. [CrossRef] [PubMed]

2. Li, H.; Gilchrist, C.L.M.; Phan, C.-S.; Lacey, H.J.; Vuong, D.; Moggach, S.A.; Lacey, E.; Piggott, A.M.; Chooi, Y.-H. Biosynthesis of a new benzazepine alkaloid nanangelenin A from Aspergillus nanangensis Involves an unusual l-kynurenine-incorporating NRPS catalyzing regioselective lactamization. J. Am. Chem. Soc. 2020, 142, 7145-7152. [CrossRef] [PubMed]

3. Gao, D.-W.; Jamieson, C.S.; Wang, G.; Yan, Y.; Zhou, J.; Houk, K.N.; Tang, Y. A Polyketide cyclase that forms medium-ring lactones. J. Am. Chem. Soc. 2021, 143, 80-84. [CrossRef] [PubMed]

4. Adam, S.; Franz, L.; Milhim, M.; Bernhardt, R.; Kalinina, O.V.; Koehnke, J. Characterization of the stereoselective P450 enzyme BotCYP enables the in vitro biosynthesis of the Bottromycin core scaffold. J. Am. Chem. Soc. 2020, 142, 20560-20565. [CrossRef] [PubMed]

5. Monagas, M.; Urpi-Sarda, M.; Sánchez-Patán, F.; Llorach, R.; Garrido, I.; Gómez-Cordovés, C.; Andres-Lacueva, C.; Bartolomé, B. Insights into the metabolism and microbial biotransformation of dietary flavan-3-ols and the bioactivity of their metabolites. Food Funct. 2010, 1, 233-253. [CrossRef]

6. $\quad$ Bianchini, L.F.; Arruda, M.F.C.; Vieira, S.R.; Campelo, P.M.S.; Gregio, A.M.T.; Rosa, E.A.R. Microbial biotransformation to obtain new antifungals. Front. Microbiol. 2015, 6, 1433. [CrossRef] [PubMed]

7. Tahir, K.; Nazir, S.; Li, B.; Khan, A.U.; Khan, Z.U.H.; Gong, P.Y.; Khan, S.U.; Ahmad, A. Nerium oleander leaves extract mediated synthesis of gold nanoparticles and its antioxidant activity. Mater. Lett. 2015, 156, 198-201. [CrossRef]

8. Abdou, R.H.; Basha, W.A.; Khalil, W.F. Subacute toxicity of Nerium oleander ethanolic extract in mice. Toxicol. Res. 2019, 35, 233-239. [CrossRef]

9. Dunn, D.E.; He, D.N.; Yang, P.; Johansen, M.; Newman, R.A.; Lo, D.C. In vitro and in vivo neuroprotective activity of the cardiac glycoside oleandrin from Nerium oleander in brain slice-based stroke models. J. Neurochem. 2011, 119, 805-814. [CrossRef]

10. Ozel, H.Z. Extracts of Nerium Species, Methods of Preparation, and Use Therefore. U.S. Patent 5135745A, 4 August 1992.

11. Rashan, L.J.; Franke, K.; Khine, M.M.; Kelter, G.; Fiebig, H.H.; Neumann, J.; Wessjohann, L.A. Characterization of the anticancer properties of monoglycosidic cardenolides isolated from Nerium oleander and Streptocaulon tomentosum. J. Ethnopharmacol. 2011, 134, 781-788. [CrossRef]

12. Aslanipour, B.; Alan, M. Therapeutic aspects of some extracts and purified cardiac glycosides obtained from Nerium oleander L. In Drug Development for Cancer and Diabetes. A Path to 2030; Apple Academic Press: New York, NY, USA, $2020 ;$ p. 79.

13. Newman, R.; Sastry, K.J.; Arav-Boger, R.; Cai, H.; Matos, R.; Harrod, R. Antiviral effects of oleandrin. J. Exp. Pharmacol. 2020, 12, 503-515. [CrossRef] [PubMed]

14. Wasfi, I.A.; Zorob, O.; Al Katheeri, N.A.; Al Awadhi, A.M. A fatal case of oleandrin poisoning. Forensic Sci. Int. 2008, 179, e31-e36. [CrossRef] [PubMed]

15. Zhou, C.; Yu, F.; Zeng, P.; Zhang, T.; Huang, H.; Chen, W.; Wu, B. Circadian sensitivity to the cardiac glycoside oleandrin is associated with diurnal intestinal P-glycoprotein expression. Biochem. Pharmacol. 2019, 169, 113622. [CrossRef]

16. Plante, K.S.; Plante, J.A.; Fernandez, D.; Mirchandani, D.; Bopp, N.; Aguilar, P.V.; Sastry, K.J.; Newman, R.A.; Weaver, S.C. Prophylactic and therapeutic inhibition of in vitro SARS-CoV-2 replication by oleandrin. bioRxiv 2020. [CrossRef]

17. Arao, T.; Fuke, C.; Takaesu, H.; Nakamoto, M.; Morinaga, Y.; Miyazaki, T. Simultaneous determination of cardenolides by sonic spray ionization liquid chromatography-ion trap mass spectrometry—a fatal case of oleander poisoning. J. Anal. Toxicol. 2002, 26, 222-227. [CrossRef] [PubMed]

18. Grote-Levi, L.M. Identification and Functional Characterization of Anti-Fibrotic Natural Compounds In Vitro. Ph.D. Thesis, Medizinische Hochschule Hannover, Hannover, Germany, 2018.

19. Milutinovic, S.; Heynen-Genel, S.; Chao, E.; Dewing, A.; Solano, R.; Milan, L.; Barron, N.; He, M.; Diaz, P.W.; Matsuzawa, S.-I.; et al. Cardiac glycosides activate the tumor suppressor and viral restriction factor promyelocytic leukemia protein (PML). PLoS ONE 2016, 11, e0152692. [CrossRef]

20. Petschenka, G.; Fei, C.S.; Araya, J.J.; Schröder, S.; Timmermann, B.N.; Agrawal, A.A. Relative selectivity of plant cardenolides for $\mathrm{Na}+/ \mathrm{K}+-A T P a s e s$ from the monarch butterfly and non-resistant insects. Front. Plant Sci. 2018, 9, 1424. [CrossRef]

21. López-Lázaro, M.; De La Peña, N.P.; Pastor, N.; Martín-Cordero, C.; Navarro, E.; Cortés, F.; Ayuso, M.J.; Toro, M.V. Anti-tumour activity of Digitalis purpurea L. subsp. heywoodii. Planta Medica 2003, 69, 701-704. [CrossRef]

22. Karuppannan, A.K.; Wu, K.X.; Qiang, J.; Chu, J.J.-H.; Kwang, J. Natural compounds inhibiting the replication of Porcine reproductive and respiratory syndrome virus. Antivir. Res. 2012, 94, 188-194. [CrossRef]

23. Wang, Y.Y.; Xiao, L.Y.; Wu, P.C.; Chen, Y.K.; Lo, S.; Hu, S.C.S.; Chen, Y.H.; Chiu, C.C.C.; Yuan, S.S.F. Orabase-formulated gentian violet effectively improved oral potentially malignant disorder in vitro and in vivo. Biochem. Pharmacol. 2020, 171, 113713. [CrossRef]

24. Laird, G.M.; Eisele, E.E.; Rabi, S.A.; Nikolaeva, D.; Siliciano, R.F. A novel cell-based high-throughput screen for inhibitors of HIV-1 gene expression and budding identifies the cardiac glycosides. J. Antimicrob. Chemother. 2013, 69, 988-994. [CrossRef] [PubMed]

25. Low, J.S.Y.; Wu, K.X.; Chen, K.C.; Ng, M.M.-L.; Chu, J.J.H. Narasin, a novel antiviral compound that blocks dengue virus protein expression. Antivir. Ther. 2011, 16, 1203-1218. [CrossRef]

26. Wang, C.; Gore, J.C.; Xie, J. High throughput screening for colorectal cancer specific compounds. Comb. Chem. High Throughput Screen. 2016, 19, 180-188. [CrossRef] 
27. Veliky, I.A.; Jones, A.; Ozubko, R.S.; Przybylska, M.; Ahmed, F.P. 5 $\beta$-hydroxygitoxigenin, a product of gitoxigenin produced by Daucus carota culture. Phytochemistry 1980, 19, 2111-2112. [CrossRef]

28. Titus, E. The metabolism of cardiac lactones by microorganisms. In Advances in applied Microbiology; Elsevier: Amsterdam, The Netherlands, 1961; pp. 279-292.

29. Ekiz, G.; Duman, S.; Bedir, E. Biotransformation of cyclocanthogenol by the endophytic fungus Alternaria eureka 1E1BL1. Phytochemistry 2018, 151, 91-98. [CrossRef]

30. Özçınar, Ö.; Tag, O.; Yusufoglu, H.; Kivçak, B.; Bedir, E.; Kıvcak, B. Biotransformation of neoruscogenin by the endophytic fungus Alternaria eureka. J. Nat. Prod. 2018, 81, 1357-1367. [CrossRef]

31. Ekiz, G.; Yılmaz, S.; Yusufoglu, H.; Kırmızıbayrak, P.B.; Bedir, E. Microbial transformation of cycloastragenol and astragenol by endophytic fungi isolated from astragalus species. J. Nat. Prod. 2019, 82, 2979-2985. [CrossRef]

32. Duman, S.; Ekiz, G.; Yılmaz, S.; Yusufoglu, H.; Kırmızıbayrak, P.B.; Bedir, E. Telomerase activators from 20(27)-octanorcycloastragenol via biotransformation by the fungal endophytes. Bioorg. Chem. 2021, 109, 104708. [CrossRef]

33. Karakoyun, Ç.; Küçüksolak, M.; Bilgi, E.; Doğan, G.; Çömlekçi, Y.E.; Bedir, E. Five new cardenolides transformed from oleandrin and nerigoside by Alternaria eureka 1E1BL1 and Phaeosphaeriasp. 1E4CS-1 and their cytotoxic activities. Phytochem. Lett. 2021, 41, 152-157. [CrossRef]

34. Kamiya, T.; Yamano, T. Microbiological transformation of a cardiac aglycone. Oxidation of hydroxyl group of gitoxigenin. Chem. Pharm. Bull. 1961, 9, 579-580. [CrossRef]

35. Nozaki, Y. Transformations of cardio-active steroids by microorganisms: Part I. microbial dehydrogenation of 3-hydroxyl group of digitalis cardiac aglycone. Agric. Biol. Chem. 1961, 25, 461-465. [CrossRef]

36. Kawaguchi, K.; Hirotani, M.; Furuya, T. Biotransformation of digitoxigenin by cell suspension cultures of Strophanthus divaricatus. Phytochemistry 1991, 30, 1503-1506. [CrossRef]

37. Repke, K.; Klesczewski, S. On the absorption spectra of cardiac poisons in sulfuric acid. Naunyn Schmiedebergs Arch. Exp. Pathologie Pharmakol. 1960, 239, 131-143.

38. Nawa, H.; Uchibaysahi, M.; Kamiya, T.; Yamano, T.; Arai, H.; Abe, M.; Uchibayashi, M.; Nawa, M.U.H. Microbiological transformation of a cardiac aglycone. Nat. Cell Biol. 1959, 184, 469-470. [CrossRef] [PubMed]

39. Yamada, A. Studies on the derivatives of cardiac aglycones of digitalis. Chem. Pharm. Bull. 1960, 8, 18-24. [CrossRef]

40. Repke, K.; Samuels, L.T. Enzymatic basis for epimerization of cardiotonic steroids at carbon 3 in rat liver. Biochemistry 1964, 3 , 689-695. [CrossRef] [PubMed]

41. Hennebert, O.; Montes, M.; Favre-Réguillon, A.; Chermette, H.; Ferroud, C.; Morfin, R. Epimerase activity of the human 11 $\beta$ hydroxysteroid dehydrogenase type 1 on 7-hydroxylated C19-steroids. J. Steroid Biochem. Mol. Biol. 2009, 114, 57-63. [CrossRef] [PubMed]

42. Templeton, J.F.; Cheung, A.H.T.; Sham, R.C.; Watson, T.R.; Jie, K. Ring-A oxygenated derivatives of $5 \alpha$-and $5 \beta$-cardenolides. J. Chem. Soc. 1983, 251-256. [CrossRef]

43. Bell-Parikh, L.C.; Guengerich, F.P. Kinetics of cytochrome P450 2E1-catalyzed oxidation of ethanol to acetic acid via acetaldehyde. J. Biol. Chem. 1999, 274, 23833-23840. [CrossRef]

44. Nagel, R.; Peters, R.J. Diverging mechanisms: Cytochrome-P450-catalyzed demethylation and $\gamma$-Lactone formation in bacterial gibberellin biosynthesis. Angew. Chem. 2018, 130, 6190-6193. [CrossRef]

45. Fuska, J.; Proksa, B.; Khandlová, A.; Šturdíkova, M. Microbial transformations of cardioglycosides. Appl. Microbiol. Biotechnol. 1987, 26, 313-317. [CrossRef]

46. Murphy, J.E. Diginatin-A new cardioactive glycoside from Digitalis lanata. J. Am. Pharm. Assoc. 1955, 44, 719-722. [CrossRef] [PubMed]

47. Linde, H.; Murphy, J.E.; Meyer, K. Chemischer Beweis der 12ß-HO-Gruppe in Diginatigenin. Helv. Chim. Acta 1959, 42, 2040-2043. [CrossRef]

48. Ashley, J.; Brown, B.; Okita, G.; Wright, S. The metabolites of cardiac glycosides in human urine. J. Biol. Chem. 1958, $232,315-322$. [CrossRef]

49. Shiratori, O. Growth inhibitory effect of cardiac glycosides and aglycones on neoplastic cells in vitro and in vivo studies. Gann Jpn. J. Cancer Res. 1967, 58, 521-528.

50. Doskotch, R.W.; Malik, M.Y.; Hufford, C.D.; Malik, S.N.; Trent, J.E.; Kubelka, W. Antitumor agents V: Cytotoxic cardenolides from Cryptostegia grandiflora (Roxb.). R. Br. J. Pharm. Sci. 1972, 61, 570-573. [CrossRef]

51. Ryer, A.I.; Marie, F. Process for the Isolation of Oleandrin. U.S. Patent 2438418A, 23 March 1948.

52. Ekiz, G. Research on Bioactive Secondary Metabolite Profile of Septofusidium Berolinense and Biotranformation of Cycloartane Type Saponins by Endophytic Fungi. Ph.D. Thesis, Department of Bioengineering, Ege University, Izmir, Turkey, 2016. 